\title{
Air mass origins influencing TTL chemical composition over West Africa during 2006 summer monsoon
}

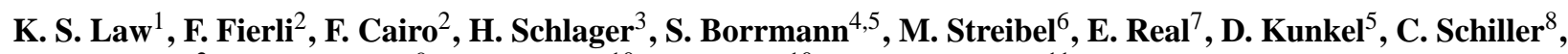 \\ F. Ravegnani ${ }^{2}$, A. Ulanovsky ${ }^{9}$, F. D'Amato ${ }^{10}$, S. Viciani ${ }^{10}$, and C. M. Volk ${ }^{11}$ \\ ${ }^{1}$ UPMC Univ. Paris 06; Université Versailles St-Quentin; CNRS/INSU, UMR 8190, LATMOS-IPSL, Paris, France \\ ${ }^{2}$ Istituto di Scienze dell'Atmosfera e del Clima, Consiglio Nazionale delle Ricerche (ISAC-CNR), Italy \\ ${ }^{3}$ DLR Institut für Physik der Atmosphäre, Oberpfaffenhofen, Germany \\ ${ }^{4}$ Institute of Atmospheric Physics, Univ. Mainz, Germany \\ ${ }^{5}$ Max-Planck Institute for Chemistry, Particle Chemistry Department, Mainz, Germany \\ ${ }^{6}$ European Ozone Research Coordinating Unit, Univ. Cambridge, UK \\ ${ }^{7}$ CEREA, ENPC/EDF, Univ. Paris-Est, France \\ ${ }^{8}$ ICG-1, Forschungszentrum Jülich, Germany \\ ${ }^{9}$ Central Aerological Observatory, Moscow, Russia \\ ${ }^{10}$ Consiglio Nazionale delle Ricerche-Istituto Nazionale di Ottica (CNR-INO), Firenze, Italy \\ ${ }^{11}$ Wuppertal University, Wuppertal, Germany
}

Received: 20 April 2010 - Published in Atmos. Chem. Phys. Discuss.: 23 June 2010

Revised: 6 October 2010 - Accepted: 8 October 2010 - Published: 17 November 2010

\begin{abstract}
Trace gas and aerosol data collected in the tropical tropopause layer (TTL) between $12-18.5 \mathrm{~km}$ by the M55 Geophysica aircraft as part of the SCOUT-AMMA campaign over West Africa during the summer monsoon in August 2006 have been analysed in terms of their air mass origins. Analysis of domain filling back trajectories arriving over West Africa, and in the specific region of the flights, showed that the M55 flights were generally representative of air masses arriving over West Africa during the first 2 weeks of August, 2006. Air originating from the midlatitude lower stratosphere was under-sampled (in the midupper TTL) whilst air masses uplifted from central Africa (into the lower TTL) were over-sampled in the latter part of the campaign. Signatures of recent (previous 10 days) origins were superimposed on the large-scale westward flow over West Africa. In the lower TTL, air masses were impacted by recent local deep convection over Africa at the level of main convective outflow $(350 \mathrm{~K}, 200 \mathrm{hPa}$ ) and on certain days up to $370 \mathrm{~K}(100 \mathrm{hPa})$. Estimates of the fraction of air masses influenced by local convection vary from 10 to $50 \%$ depending on the method applied and from day to day during the
\end{abstract}

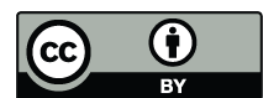

Correspondence to: K. S. Law (kathy.law@latmos.ipsl.fr) campaign. The analysis shows that flights on 7,8 and $11 \mathrm{Au}-$ gust were more influenced by local convection than on 4 and 13 August allowing separation of trace gas and aerosol measurements into "convective" and "non-convective" flights. Strong signatures, particularly in species with short lifetimes (relative to $\mathrm{CO}_{2}$ ) like $\mathrm{CO}, \mathrm{NO}$ and fine-mode aerosols were seen during flights most influenced by convection up to 350$365 \mathrm{~K}$. Observed profiles were also constantly perturbed by uplift (as high as 39\%) of air masses from the mid to lower troposphere over Asia, India, and oceanic regions resulting in import of clean oceanic (e.g. $\mathrm{O}_{3}$-poor) or polluted air masses from Asia (high $\mathrm{O}_{3}, \mathrm{CO}, \mathrm{CO}_{2}$ ) into West Africa. Thus, recent uplift of $\mathrm{CO}_{2}$ over Asia may contribute to the observed positive $\mathrm{CO}_{2}$ gradients in the TTL over West Africa. This suggests a more significant fraction of younger air masses in the TTL and needs to taken into consideration in derivations of mean age of air. Transport of air masses from the mid-latitude lower stratosphere had an impact from the midTTL upwards (20-40\% above $370 \mathrm{~K}$ ) during the campaign period importing air masses with high $\mathrm{O}_{3}$ and $\mathrm{NO}_{\mathrm{y}}$. Ozone profiles show a less pronounced lower TTL minimum than observed previously by regular ozonesondes at other tropical locations. Concentrations are less than $100 \mathrm{ppbv}$ in the lower TTL and vertical gradients less steep than in the upper TTL. The air mass origin analysis and simulations of in-situ net

Published by Copernicus Publications on behalf of the European Geosciences Union. 
photochemical $\mathrm{O}_{3}$ production, initialised with observations, suggest that the lower TTL is significantly impacted by uplift of $\mathrm{O}_{3}$ precursors (over Africa and Asia) leading to positive production rates (up to $2 \mathrm{ppbv}$ per day) in the lower and mid TTL even at moderate $\mathrm{NO}_{\mathrm{x}}$ levels. Photochemical $\mathrm{O}_{3}$ production increases with higher $\mathrm{NO}_{\mathrm{x}}$ and $\mathrm{H}_{2} \mathrm{O}$ in air masses with $\mathrm{O}_{3}$ less than 150 ppbv.

\section{Introduction}

Understanding the processes that govern the chemical composition, microphysics and transport in the tropical upper troposphere (UT) and lower stratosphere (LS) is important for the quantification of transport of trace gases and aerosols into the stratosphere, where they can impact stratospheric $\mathrm{O}_{3}$ depletion and the stratospheric water budget. This region, designated the tropical tropopause layer (TTL), represents a transition zone between the troposphere and stratosphere and has been defined in a number of different ways. A comprehensive review of the TTL was given by Fueglistaler et al. (2009) who, for stratospheric purposes, prefer to define the TTL as the region characterised by slow ascending motion driven by radiative heating and the largescale Brewer-Dobson circulation extending from the region above main convective outflow (neutral buoyancy) at $355 \mathrm{~K}$ $(150 \mathrm{hPa}, 14 \mathrm{~km})$ up to $425 \mathrm{~K}(70 \mathrm{hPa}, 18.5 \mathrm{~km})$. This region is bounded laterally by the position of the sub-tropical jets (STJs) which limits meridional transport in the lower part of the TTL but not in the upper TTL (e.g. see Volk et al., 2000). Other definitions (e.g. Gettelman et al., 2004) have fixed the lower boundary at the level of main deep convective outflow $(350 \mathrm{~K}, 200 \mathrm{hPa}, 12.5 \mathrm{~km})$ although Fueglistaler et al. (2009) point out that air is largely subsiding at these levels. However, the actual quantification of the flux of trace gases into the stratosphere will depend on the composition of the air masses that enter the TTL, their residence time in the TTL before upward transport as well as processes that can change their concentrations (chemistry, microphysics, in-mixing from mid-latitudes). Quantification of processes influencing the chemical composition of the TTL is also important for climate since several trace gases, namely $\mathrm{H}_{2} \mathrm{O}, \mathrm{O}_{3}$ and $\mathrm{CO}_{2}$, make significant contributions to the Earth's radiative budget at these altitudes. Tropospheric $\mathrm{O}_{3}$, which can be produced downwind from convective regions from lightning $\mathrm{NO}_{\mathrm{x}}$ or following uplift of ozone precursors (e.g. Pickering et al., 1996), governs the global oxidizing capacity and the lifetime of several greenhouse gases such as $\mathrm{CH}_{4}$, through the production of the hydroxyl radical $(\mathrm{OH})$. Also, the TTL constitutes a major source of new particle formation probably contributing to the maintenance of the global, stratospheric Junge aerosol layer (Brock et al., 1995; Borrmann et al., 2010).
In this paper, we present an analysis of air mass origins influencing chemical composition of the TTL over West Africa based on aircraft data collected during the summer monsoon in 2006 as part of a joint AMMA (African Monsoon Multidisciplinary Analysis) and SCOUT-O3 (StratosphericClimate Links with Emphasis on the Upper Troposphere and Lower Stratosphere) airborne campaign. We analyse flights made by the M55-Geophysica aircraft between 12 and $20 \mathrm{~km}$ during August 2006 as part of a multi-aircraft measurement deployment. The SCOUT-AMMA M55 aircraft campaign is one of the first campaigns to take place in the Northern Hemisphere summer in a region influenced by both the African and Asian monsoons. Recent tropical campaigns have taken place in locations downwind of Africa over central America as part of the Tropical Convective Systems and Processes (TCSP) in summer 2005 and Tropical Composition, Cloud and Climate Coupling (TC4) experiments in summer 2007 (Toon et al., 2010; Selkirk et al., 2010). Previous campaigns took place at other times of year and focused primarily on diagnosing contributions from local deep convection and advection of air from the mid-latitude lower stratosphere. These campaigns took place in Southern Hemisphere summer over Australia (Brunner et al., 2009) and Brazil (Pommereau et al., 2009; Huntrieser et al., 2008) and Northern Hemisphere winter over Costa Rica (e.g. Marcy et al., 2007). One of the main aims of the West African M55 campaign was to quantify the contribution from different air mass origins on TTL chemical composition during the summer monsoon. At this time of year the TTL over West Africa can be impacted a) by advection of air masses from upwind regions, and b) by recent regional convective uplift. Air masses advected into the TTL over West Africa may have been influenced by uplift from the lower troposphere over upwind regions (e.g. Asia), intrusion of air from the mid-latitude lower stratosphere or cross-hemispheric transport of air masses from the Southern Hemisphere.

The meteorological situation during the summer monsoon over West Africa is discussed in Sect. 2. A brief description of the M55 campaign is given in Sect. 3. The fractions of air masses arriving from different upwind regions via large-scale transport are estimated based on back trajectory calculations to quantify the influence of different origins (Sect. 4). Comparison of results calculated for a West African domain with those calculated in the region or along M55 flight tracks allows the flights to be put into a broader context during August 2006. The influence of recent convective uplift over central and western Africa, diagnosed using coincidences between back trajectories and convective cloud tops is discussed in Sect. 5. Results are compared with results from mesoscale model simulations (Fierli et al., 2010). The results are used to divide the M55 flights into those more or less influenced by recent convective uplift over Africa. The influence of large-scale transport and regional convective uplift on measured M55 trace gas and aerosol profiles is then discussed in Sect. 6. Conclusions are presented in Sect. 7. 


\section{Meteorological situation}

A detailed discussion about the characteristics of the summer monsoon over West Africa and comparisons between 2006 and 1990-2005 can be found in Janicot et al. (2008). A description of the general meteorological situation during July and August 2006 in the upper troposphere and lower stratosphere (UTLS) including relation to the passage of convective systems is also given in Cairo et al. (2010). By way of a brief summary, the circulation in the lower troposphere is governed by dry north-easterly Harmattan winds circulating round the Saharan anticyclone, and moist south-westerly winds circulating round the southern Atlantic Santa Helena anticyclone which converge at the Inter-Tropical Convergence Zone (ITCZ) around $10^{\circ} \mathrm{N}$. During August 2006, the surface Inter-Tropical Front reached as far north as $12 \mathrm{~N}$. This convergence zone, and the presence of elevated terrain to the east, leads to the formation of large organized mesoscale convective systems (MCSs) which are modulated by the propagation of African easterly waves tracking from east to west and the position and strength of the African easterly jet (AEJ): a mid-level thermal wind between $10-15^{\circ} \mathrm{N}$. In August 2006, convective activity and resulting precipitation were slightly enhanced compared to the 1990-2005 average (Janicot et al., 2008).

Trace gases and aerosols injected into the TTL are transported rapidly westward due to the existence of the Tropical Easterly Jet (TEJ) at $200 \mathrm{hPa}$ induced by upper level anticyclones related to the African and Asian monsoons. This can also lead to transport of lower stratospheric air into the TTL over the Himalayas (Gettleman and Forster, 2002). Whilst the TEJ has maximum speeds over the Indian Ocean it extends into West Africa in July and August with a core evident around $10-30^{\circ} \mathrm{W}$. The TEJ over West Africa was stronger compared to the mean in August 2006 (Janicot et al., 2008). This westward flow dominates the large-scale circulation but chemical composition over West Africa can also be influenced by more recent uplift into the TTL. As noted in Fuglistaler et al. (2009) and references therein, the propagation or breaking of waves such as planetary scale, quasistationary Rossby waves (to the west) or Kelvin waves (to the east) can lead to transport of air from the stratosphere to the troposphere. Propagation of Kelvin waves can also modulate convection although Janicot et al. (2008) note that this activity was low in August 2006 over West Africa. Transport of air masses between the extra-tropical stratosphere and the tropics is also influenced by the phase of the Quasi-Biennial Oscillation (QBO). As discussed in Cairo et al. (2010), the QBO was in the process of switching from westerly to easterly winds in the lower stratosphere and thus from a westerly phase more likely to favour extra-tropical transport into the tropical lower stratosphere to an easterly phase where this is less likely (e.g. O'Sullivan and Dunkerton, 1997). Analysis of $\mathrm{N}_{2} \mathrm{O}$ data collected during the M55 campaign over West Africa estimated a contribution from in-mixing of aged extra-tropical air into the West African TTL varying from $8 \%$ at $375 \mathrm{~K}$ to $30 \%$ at $390 \mathrm{~K}$ (Homan et al., 2010).

Transport of pollutants into the upper troposphere over Asia by deep convection followed by westward transport has been identified as a source of carbon monoxide over West Africa (Barret et al., 2008). Analysis of Microwave Limbs Sounder (MLS) data and global model results showed an influence from this source above $150 \mathrm{hPa}$ over West Africa with maximum concentrations around $25^{\circ} \mathrm{N}$. Convective uplift of moist air masses over the Bay of Bengal and China Sea followed by dehydration during transport towards northwest India (around the upper level anticyclone associated with the Asian monsoon) has also been used to explain the water vapour maximum observed in MLS water vapour data at $100 \mathrm{hPa}$ over the Himalayas (James et al., 2008). Analysis of water vapour data collected on the M55 during SCOUTAMMA in August 2006 have been linked to this convective uplift followed by westward transport leading to enhanced water vapour concentrations over West Africa (Schiller et al., 2009).

At lower altitudes in the upper troposphere $(200 \mathrm{hPa})$, $\mathrm{CO}$ maxima were observed further south in satellite and MOZAIC CO data during summer 2006, especially over central Africa with a maximum at the Equator. This has been explained by convective uplift of biomass burning pollutants (located south of the Equator at this time of year) and recirculation southwards by the large-scale Hadley circulation (e.g. Barret et al., 2008). Westward transport of these emissions by the TEJ over southern West Africa may also explain higher $\mathrm{CO}$ concentrations in the upper troposphere over this region. Mari et al. (2008) examined this cross-hemispheric transport in detail showing that it is episodic and dependent on the strength of lower and mid-tropospheric transport from central Africa into the Gulf of Guinea. During periods when this transport is less active (e.g. 3-9 August 2006), pollutants remain trapped over the continent before being either transported directly to West Africa in the midtroposphere or to the north-east where they can be convectively uplifted into the upper troposphere. During AMMA, polluted plumes originating from central African biomass burning were clearly observed in the mid-troposphere over the Gulf of Guinea (Reeves et al., 2010) as a result of direct transport in the lower/mid-troposphere. Real et al. (2010) also found evidence for transport of biomass burning plumes into the lower TTL over West Africa (M55 flight on $13 \mathrm{Au}-$ gust, 2006).

Deep convection over western and central Africa also plays an important role in influencing trace gas concentrations in the TTL. During the monsoon season, large organized MCSs develop on a regular basis resulting in transport of air into the upper troposphere albeit with large-scale subsidence in surrounding regions at the level of convective outflow (around $200 \mathrm{hPa}$ ). Their impact on trace gas concentrations in the TTL is complex and will depend on where air masses were uplifted, on mixing with air in the upper 
troposphere, as well as on possible liquid and ice phase cloud processing. Convective systems are also a significant source of lightning $\mathrm{NO}_{\mathrm{x}}$ over West Africa (Höller et al., 2009) which can lead to photochemical $\mathrm{O}_{3}$ production downwind (Sauvage et al., 2007a; Barret et al., 2010).

In summary, the chemical composition of the TTL over West Africa is influenced by transport of air masses into the region primarily from the east. Chemical composition can also be influenced by additional inputs from the lower stratosphere, by cross-hemispheric transport of air masses from central Africa, or by local deep convection over Africa. The contribution of these different sources is examined in Sects. 4 and 5 .

\section{The M55 SCOUT-AMMA airborne campaign}

The M55-Geophysica campaign, which took place from 1 to 16 August 2006, was part of a larger AMMA chemistry and aerosol field intensive designed to characterize the processes influencing chemical composition over West Africa. The British BAe-146 (B146), French Falcon F-20 (FF-20) and ATR-42 were based in Niamey, Niger $\left(13.5^{\circ} \mathrm{N} 2.2^{\circ} \mathrm{E}\right)$ and the M55 and DLR-Falcon (DF-20) were based in Ouagadougou, Burkina Faso $\left(12.4^{\circ} \mathrm{N},-1.5^{\circ} \mathrm{E}\right)$. Details about the coordinated aircraft deployment and main findings can be found in Reeves et al. (2010). In this paper, we focus on analysis of M55 data, which sampled the TTL and LS between 12 and $20 \mathrm{~km}$. The M55 made 5 local flights on 4, 7, 8, 11 and 13 August with transits to and from Ouagadougou on 1 and 16 August 2006. Measurements were made of a wide variety of trace gases including $\mathrm{O}_{3}, \mathrm{CO}, \mathrm{H}_{2} \mathrm{O}, \mathrm{CO}_{2}, \mathrm{CH}_{4}, \mathrm{NO}, \mathrm{NO}_{\mathrm{y}}$, $\mathrm{N}_{2} \mathrm{O}$, as well as cloud and aerosol microphysics. A detailed description about the objectives of each flight, the aircraft payload, instrument accuracy as well as the main features observed along individual flights is given in Cairo et al. (2010). A brief summary is given here of the measurements used in this study. Measurements of $\mathrm{O}_{3}$ were made using FOZAN (Fast OZone ANalyser) (Yushkov et al., 1999), $\mathrm{H}_{2} \mathrm{O}$ using FISH (Fast In situ Stratospheric Hygrometer) (Schiller et al., 2009), $\mathrm{CO}_{2}$ using HAGAR (High Altitude Gas AnalyzeR) (Volk et al., 2000; Homan et al., 2010), $\mathrm{NO}$ and $\mathrm{NO}_{\mathrm{y}}$ using SIOUX (see Voigt et al., 2008 and references therein), CO using COLD (Cryogenically Operated Laser Diode) (Viciani et al., 2008), fine-mode aerosols using COPAS (COndensation PArticle counter Systems) (Borrmann et al., 2010), and back-scatter from aerosols by MAS (Multiwavelength Aerosol Scatterometer) (Adriani et al., 1999).

Figure 1 shows the M55 flight tracks over western Africa, colour-coded in terms of potential temperature along the flights. The flights on 4 and 13 August, to the south coast of West Africa, were aimed at characterizing the large-scale chemical composition. Possible transport of biomass burning emissions into the upper troposphere was also explored on 13 August (see Real et al. (2010) for detailed analysis).

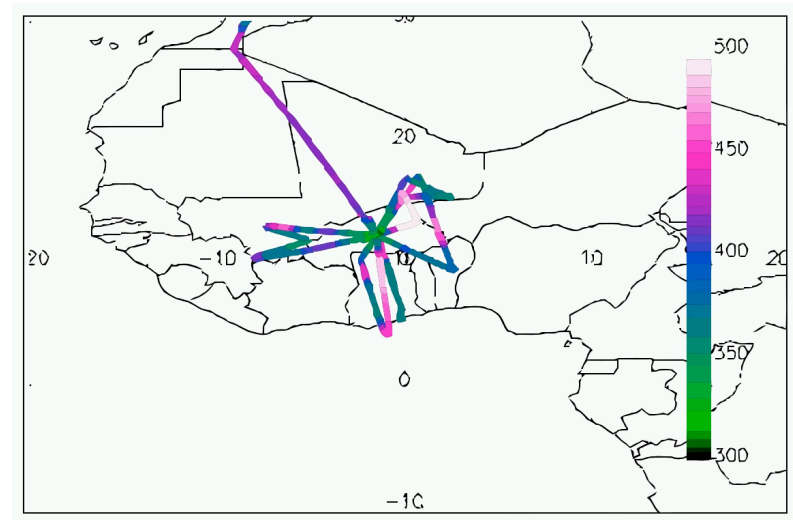

Fig. 1. M55 flight tracks over West Africa, colour coded in potential temperature $(\mathrm{K})$ along the flights.

The flight on 7 August attempted to fly in the wake of an MSC over Mali whilst the flight on 11 August flew in the aged outflow of a large MCS. A CALIPSO validation flight on 8 August 2006 also encountered convective outflow. Fierli et al. (2010) discuss the impact of local deep convection in more detail (see Sect. 5). Analysis of M55 data collected over West Africa is also reported in several recent papers and includes comparisons with data collected in other recent tropical campaigns over Australia and Brazil (Schiller et al., 2009; Homan et al., 2010; Borrmann et al., 2010). Results from this work are compared to results from these papers where appropriate.

Examination of average observed temperature and MAS aerosol backscatter profiles collected during the campaign (Fig. 2) provides information about the general vertical structure of the TTL over West Africa. Figure 2 (left panel) shows the average temperature profile as a function of potential temperature acquired south of $17.5^{\circ} \mathrm{N}$. The average cold point tropopause can clearly be seen at around $375 \mathrm{~K}$ although it varied by $\pm 5 \mathrm{~K}$ between different flights. Analysis of data collected over Costa Rica during TCSP/TC4 showed similar results (Selkirk et al., 2010) as did tropical radiosonde data (Fueglistaler et al., 2009). The total number of observations at a given theta level (Fig. 2 central panel) shows that the lower TTL was the most heavily sampled during the campaign. The right panel shows the fraction of observations in cloudy/hazy air masses derived from volume backscatter ratios greater than 1.2 measured with MAS (Adriani et al., 1999). There is a bimodal distribution with peaks at $320 \mathrm{~K}$ and $350 \mathrm{~K}$ representing main convective outflow altitudes. Above this level there is a small percentage (around 0.01\%) of cloud/haze observations up to about $410 \mathrm{~K}$ suggesting that tropospheric influence may not have extended much above this level during the campaign over West Africa although some evidence for convective overshooting has been found (Khaykin et al., 2009). A thin aerosol layer was also observed in the LS at $475 \mathrm{~K}$ related to the presence of volcanic aerosols (Borrmann et al., 2010). 


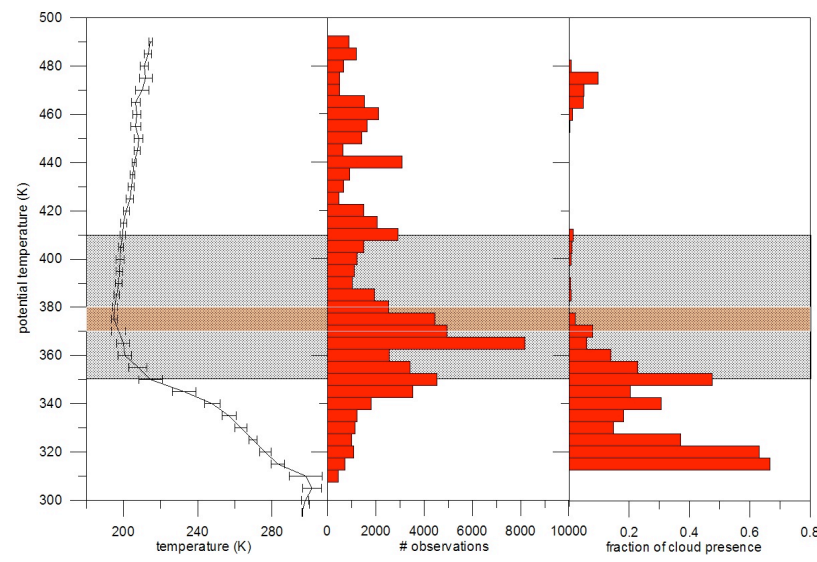

Fig. 2. Left panel: temperature versus potential temperature as measured along the M55 flights between 1-16 August 2006. Only data southward of $17.5^{\circ} \mathrm{N}$ were used to calculate averages. Bars denote one standard deviation. Middle panel: total number of observations in seconds spent at a given theta level versus potential temperature. Right panel: fraction of observations in cloudy (hazy) air, defined as air masses with Volume Backscatter Ratio $>1.2$. Grey shading denotes main TTL region and brown shading the tropopause. See text for details.

For the purposes of this analysis we use the following definitions: top of TTL at $425 \mathrm{~K}(70 \mathrm{hPa}, 18.5 \mathrm{~km})$ above which air is essentially stratospheric, the mid-TTL as the boundary between the upper and lower TTL at $370 \mathrm{~K}(100 \mathrm{hPa}$, $16.5 \mathrm{~km}$ ) just below where the cold point tropopause is located, and the lower TTL between the mid-TTL and the lower boundary defined by the altitude of maximum of convective outflow at $350 \mathrm{~K}(200 \mathrm{hPa}, 12.5 \mathrm{~km})$. The layer above the altitude of maximum convective outflow $(355 \mathrm{~K}, 150 \mathrm{hPa}$, $14 \mathrm{~km}$ ) is also of interest.

\section{Large-scale transport}

In order to identify the impact of recent air mass origins on measured chemical composition, 10 day reverse domain filling trajectories from a $0.5^{\circ}$ grid covering West Africa $\left(10^{\circ} \mathrm{E}\right.$ to $40^{\circ} \mathrm{W} ; 5$ to $25^{\circ} \mathrm{N}$ ) were calculated at 4 pressure levels from 1 to 16 August, 2006. Results based on 20-day back trajectories gave very similar results (not shown). These levels correspond to the main boundaries of interest listed in the previous section, i.e. 70, 100, 150 and $200 \mathrm{hPa}$. Trajectories were calculated using European Center for Medium Range Weather Forecast (ECMWF) analyses with 6-h time resolution producing an ensemble of 120000 air parcels. As an example, Fig. 3 shows the end points of back trajectories arriving at the 4 pressure levels on 7 August, 2006 at 12 Universal Time (UT) coloured by pressure difference with respect to the arrival point along each trajectory (blue isobaric, yellow ascent from the troposphere). The primary flow in the TTL is zonal and westward but with important fractions

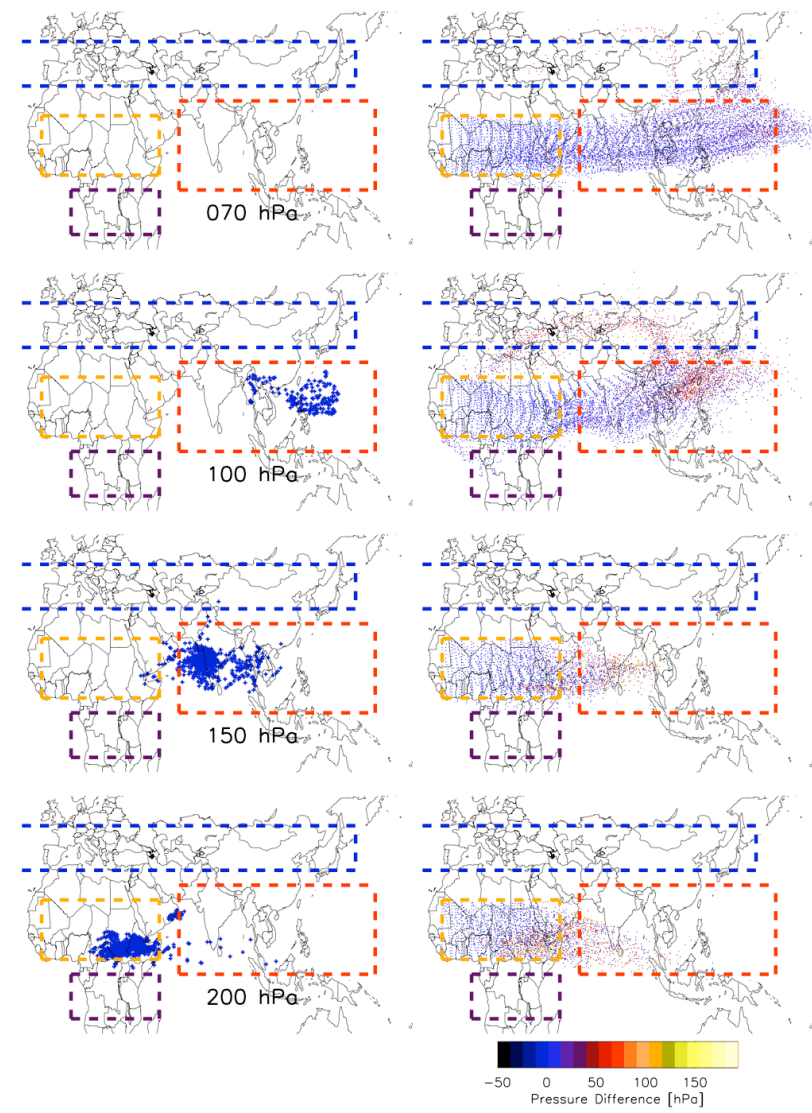

Fig. 3. Right panels: endpoints of 10 day reverse domain filling trajectories over West Africa, arriving at $200 \mathrm{hPa}, 150 \mathrm{hPa}, 100 \mathrm{hPa}$ and $70 \mathrm{hPa}$ on 7 August 2006. Dashed boxes represent main regions of origin (see Table 1). Colours show the pressure difference along each back trajectory with respect to the arrival point. Left panels: location of trajectories crossing $400 \mathrm{hPa}$ during transport to West Africa.

of air coming from Asian mid-latitudes at $100 \mathrm{hPa}$ and, to a lesser extent at $70 \mathrm{hPa}$. The Asian Monsoon region impacts $150 \mathrm{hPa}$ while $200 \mathrm{hPa}$ is sensitive to African convection. The left panel shows where air masses were uplifted from below $400 \mathrm{hPa}$ at the different levels. Similar results were found for the other days during the campaign.

The air parcel ensembles for each day of the campaign were used to define 4 main regions of recent (10 day) origin which might then superimpose particular chemical characteristics on the atmospheric composition in the large-scale westward flow (see dashed boxes in Fig. 3 and Table 1). The first two regions cover air masses arriving at all altitudes from Northern Hemisphere $(\mathrm{NH})$ mid-latitudes $\left(>35^{\circ} \mathrm{N}\right)$ and Southern Hemisphere (SH) central Africa. The third and fourth regions identify air masses arriving from the lower and mid troposphere (1000-400 hPa) over Asia and Africa. The results were used to estimate the fraction of air parcels having spent at least $6 \mathrm{~h}$ in a given region over the previous 10 
Table 1. Latitudes, longitudes and pressures used to define regions of TTL air mass origins (see text for details).

\begin{tabular}{lrrr}
\hline Region & Latitudes & Longitudes & Pressure range (hPa) \\
\hline Northern Hemisphere mid-latitudes & $35-50^{\circ} \mathrm{N}$ & $25^{\circ} \mathrm{W}-150^{\circ} \mathrm{E}$ & $50-1000$ \\
Southern Hemisphere Central Africa & $0-15^{\circ} \mathrm{S}$ & $5-50^{\circ} \mathrm{E}$ & $50-1000$ \\
Asian troposphere & $0-30^{\circ} \mathrm{N}$ & $60-160^{\circ} \mathrm{E}$ & $400-1000$ \\
African troposphere & $5-25^{\circ} \mathrm{N}$ & $10^{\circ} \mathrm{W}-50^{\circ} \mathrm{E}$ & $400-1000$ \\
\hline
\end{tabular}

days before reaching the West African domain at the 4 prescribed pressure altitudes for each day of the campaign and are shown in Fig. 4. Results were also calculated for a subdomain covering the region where the M55 flights took place $\left(8^{\circ} \mathrm{E}\right.$ to $5^{\circ} \mathrm{W} ; 5$ to $15^{\circ} \mathrm{N}$ ) (see Fig. $4 \mathrm{~b}$ ). The percentages expressed in Fig. 4 can be viewed as the fraction of air coming from regions other than zonally isobaric flow in the TTL. It is not expected that this analysis identifies all possible origins nor are they mutually exclusive.

First considering air mass origins over the whole West African domain during the campaign period (Fig. 4a). Air masses originating from $\mathrm{NH}$ mid-latitudes have the most impact on altitudes in the mid and upper TTL over West Africa with a mean influence over 16 days of $41 \%$ and $15 \%$ at $100 \mathrm{hPa}$ and $70 \mathrm{hPa}$, respectively. These air masses have been transported around the Tibetan High, especially at $100 \mathrm{hPa}$. However, there is significant daily variability, ranging from 13 to $73 \%$ at $100 \mathrm{hPa}$, for example. The average values at $100 \mathrm{hPa}$ are in reasonable agreement with Konopka et al. (2009) who estimated the fraction of air masses entering the TTL from the LS associated with the Asian summer monsoon upper level anticyclone. A significant fraction of air masses are also influenced by uplift of tropospheric air over Asia, especially at $150 \mathrm{hPa}(39 \%$ on average) and $100 \mathrm{hPa}$ ( $21 \%$ on average). Uplift of air masses over Africa (north of the Equator) has the most impact at $200 \mathrm{hPa}$ (52\% on average). In this analysis, based on trajectories calculated using ECMWF analyses, uplift from below $400 \mathrm{hPa}$ is considered. Further analysis (not shown) shows that most trajectories originate from the mid-troposphere. Whilst such trajectories are able to capture large-scale uplift they are likely to underestimate uplift associated local deep convection. In this case they may underestimate the number of convective events as well as vertical velocities and the altitude to which convection has an impact (e.g. see Fierli et al., 2010). Therefore, the results presented in Fig. 4 may represent a lower limit. Air masses originating from SH central Africa (all altitudes) have their main influence in the latter half of the campaign period leading to a lower average influence (6\%). Transport through this region is associated with southerly deviations in the position of the TEJ. Interestingly, at the end of the campaign period, these air masses also influence $150 \mathrm{hPa}$ and $200 \mathrm{hPa}$ (up to 23\%) related to the development of large MCSs over Chad/Sudan (Real et al., 2010).
We now address whether, and to what extent, the sampling of the M55 was representative of the air masses arriving over West Africa during the campaign. The fraction of trajectories passing through the different regions before arriving in the sub-domain where the flights took place is shown in Figure 4b. In general, the M55 flight region experienced similar fractions of air masses originating from the free troposphere over Africa at $200 \mathrm{hPa}$ (56\% on average), Asia at $150 \mathrm{hPa}(39 \%)$, and $100 \mathrm{hPa}(21 \%)$. At $100 \mathrm{hPa}$, the M55 region saw less air arriving from $\mathrm{NH}$ mid-latitudes $(21 \% \mathrm{com}-$ pared to $41 \%$ at $100 \mathrm{hPa}$ ) and more from SH central Africa (13\% compared to $6 \%$ at $200 \mathrm{hPa}$ ) compared to the larger West African domain. These biases need to be borne in mind when analysing M55 flight data.

We now focus on discussing the origins of air masses sampled by the M55 in more detail. Figure 5 shows the starting points of 10-day back trajectories initialised along the M55 flight tracks (on average 200 points per flight with 1 min time interval). The results are colour-coded in terms of pressure variations along the back trajectory (left panel), and pressure at the ending point on the M55 flight path (right panel). As noted already, air in the upper TTL has mainly resided in the TTL before arriving over West Africa and shows only small theta deviations over the last 10 days. A noteworthy fraction of upper TTL $(<100 \mathrm{hPa})$ air originates from further north and west over Japan and eastern China/Korea consistent with the NH mid-latitude origin shown in Fig. 4. Figure 5 also shows that the origin of air in the mid TTL (around $150 \mathrm{hPa}$ ) is more widespread with larger pressure variations, and air masses uplifted from Asia, India and, to a lesser extent, the Middle East.

To explore this further, Fig. 6 shows scatter plots of the difference in pressure versus the difference in latitude along the back trajectories coloured with $\mathrm{O}_{3}$ (left panel) and $\mathrm{H}_{2} \mathrm{O}$ (right panel) observed along the M55 flights. Ozone concentrations in air masses originating from the mid-lower troposphere are generally below $125 \mathrm{ppbv}$ and sometimes lower than $50 \mathrm{ppbv}$. This variability can be due to uplift of $\mathrm{O}_{3}$ poor (marine) or rich (polluted) air masses and mixing with air masses already residing in the TTL. Cross-hemispheric transport of air masses via the TEJ with high $\mathrm{O}_{3}$ and low $\mathrm{H}_{2} \mathrm{O}$ are also evident (negative latitude changes and small pressure changes). The variability in observed $\mathrm{O}_{3}$ concentrations is discussed further in Sect. 6. Concerning $\mathrm{H}_{2} \mathrm{O}$, Schiller et al. (2009) 


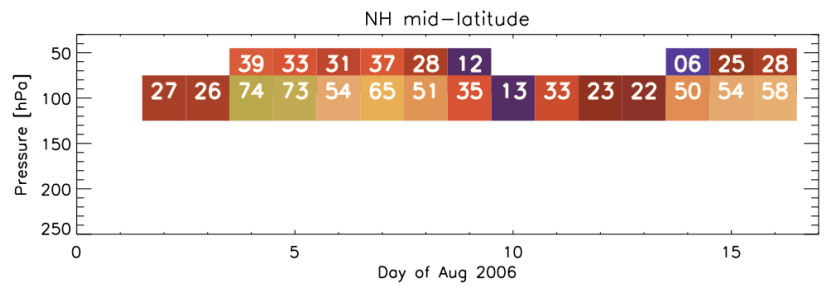

SH Africa

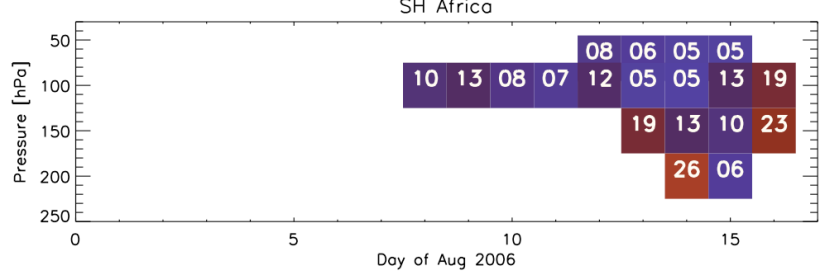

Asia Troposphere

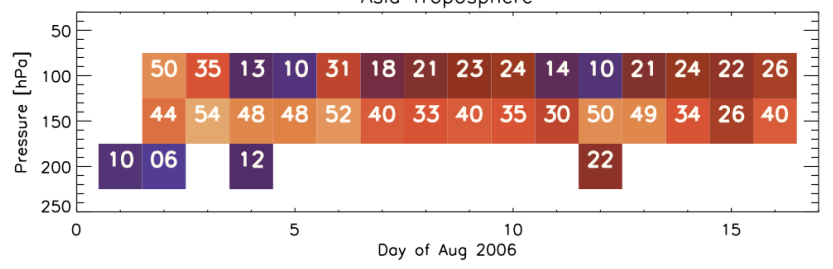

Africa Troposphere

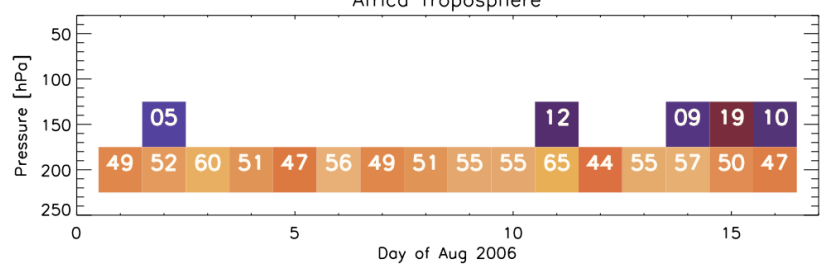

Fig. 4a. Relative contribution of different air mass origin regions (defined in Table 1) based on 10 day back trajectories to air masses arriving over the West African domain $\left(10^{\circ} \mathrm{E}\right.$ to $40^{\circ} \mathrm{W}$ and 5 to $25^{\circ} \mathrm{N}$ ) between 1-16 August 2006. Colour codes the percentage of regional influence in terms of fraction of trajectories passing through a particular region (blue $=$ low, red-orange $=$ medium, yellow $=$ high). This value is also expressed numerically in each coloured cell. Note that trajectories can pass through more than one region leading to total fractions of more than $100 \%$.

noted that the TTL over West Africa during summer 2006 was moister compared to other tropical campaigns. Their analysis pointed to convective uplift of moist air masses associated with the Asian monsoon followed by dehydration during westward transport around the upper level anticyclone leading to drying, but nevertheless moister air masses arriving over West Africa. This analysis is also in agreement with the study of James et al. (2008) who investigated the moist $\mathrm{H}_{2} \mathrm{O}$ anomaly associated with the summer Asian monsoon seen in MLS data. This is confirmed by Fig. 6 which shows that a significant number of air masses sampled by the M55 were uplifted. At the point of measurement, although mainly low $\mathrm{H}_{2} \mathrm{O}$ was observed, higher $\mathrm{H}_{2} \mathrm{O}$ concentrations were also observed. Figure 7 shows where 10 day back trajectories arriving along the M55 flights left the lower troposphere, also
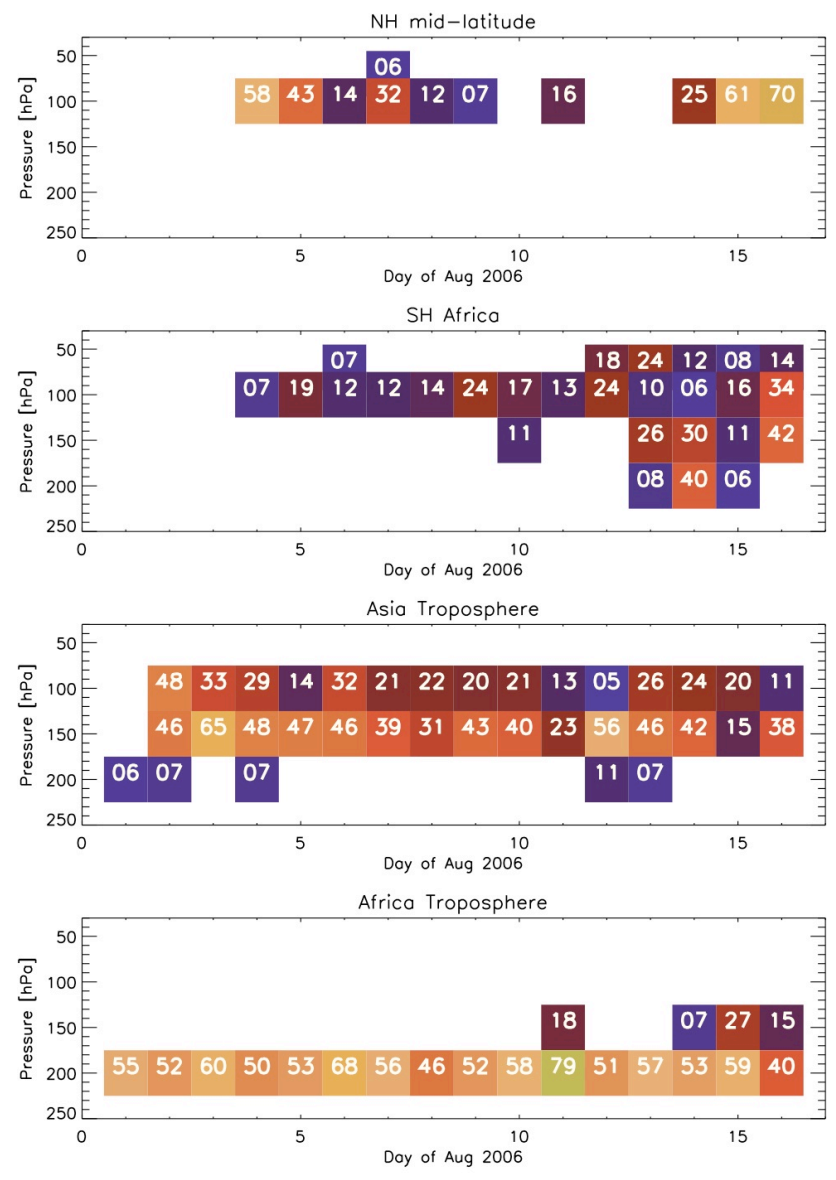

Fig. 4b. Same as Fig. 4a but based on 10 day back trajectories traced back from a sub-domain including the M55 flight tracks $\left(8^{\circ} \mathrm{E}\right.$ to $5^{\circ} \mathrm{W}$ and 5 to $15^{\circ} \mathrm{N}$ ).

coded in terms of $\mathrm{O}_{3}$ (left panel) and $\mathrm{H}_{2} \mathrm{O}$ (right panel). In this case a more strict criteria was used to define uplift as being from below $800 \mathrm{hPa}$. The points on the maps, although scattered, show a band extending from eastern Africa to south-east Asia. Interestingly, for $\mathrm{H}_{2} \mathrm{O}$ there appears to be an east-west gradient in concentrations with air masses associated with more recent uplift over the Arabic peninsula having higher $\mathrm{H}_{2} \mathrm{O}$ concentrations upon arrival over West Africa than those originating from further east over Asia. Recent convective influence could also explain higher $\mathrm{H}_{2} \mathrm{O}$ concentrations in the TTL over West Africa.

This analysis shows that, in general, air in the TTL over West Africa, and in the region of the M55 flights, was influenced by a variety of more recent (10 day) air mass origins superimposed on the large-scale westward flow. The mid and upper TTL was influenced by recent import of lower stratospheric air from NH mid-latitudes. The mid-TTL also shows a significant influence from air masses uplifted from the lower and mid troposphere over Asia, and India whereas the lower TTL was mainly impacted by air recently uplifted from the troposphere over Africa. 

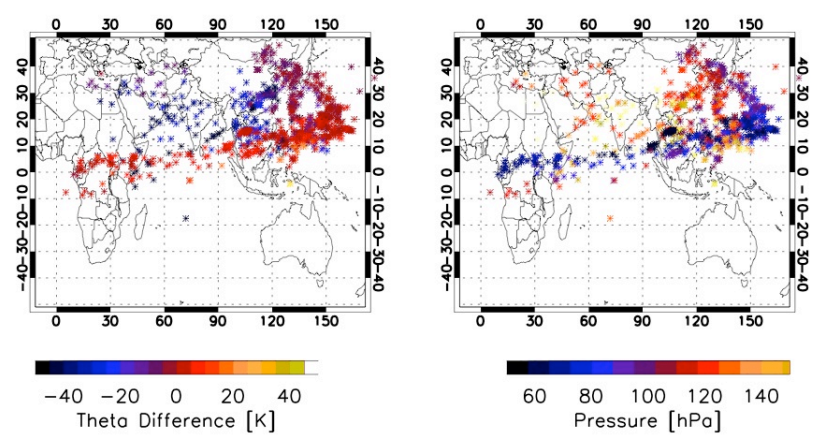

Fig. 5. Starting points of 10-day back trajectories initialised along the M55 flight tracks south of $18^{\circ} \mathrm{N}$ colour coded in terms of theta variations (K) along the back trajectories (left panel) and pressure at the starting point of the back trajectory, i.e. along the M55 flight path (right panel).
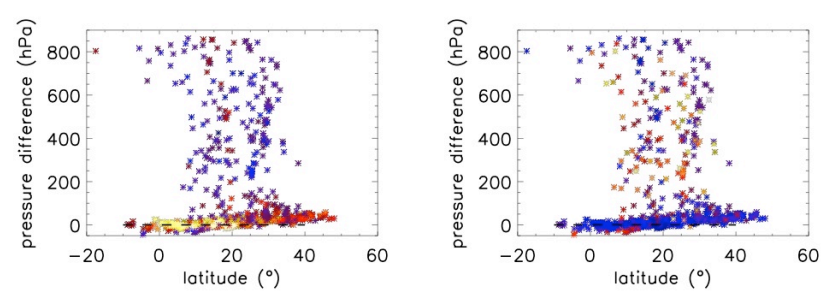

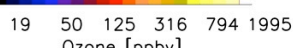

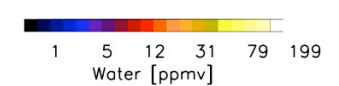

Fig. 6. Scatter plot of the pressure differential versus latitude differential along the back trajectories starting from M55 flight tracks, colour coded in terms of ozone in ppbv (left panel) and water vapour in ppmv (right panel) observed along the flights.

\section{Recent regional convection}

The influence of local convective uplift occurring over western and central Africa is examined further in this section. Coincidences were identified between ECMWF back trajectories over the whole West African domain (as described in the previous section) and convective cloud tops derived from Meteosat Second Generation (MSG) Infrared Channel $(10.6 \mu \mathrm{m})$ observations. A convective cloud was identified when cloud top radiance temperatures were below $200 \mathrm{~K}$. The time resolution of the MSG images was $30 \mathrm{~min}$ and horizontal resolution ranged from 5 to $10 \mathrm{~km}$. Since the images covered the longitudinal band $30^{\circ} \mathrm{W}$ to $40^{\circ} \mathrm{E}$, the convection was local and relatively recent, i.e. given the average westward speed of the MCS, not older that 3-4 days. Figure 8 shows daily maps of this diagnosed convective impact at $200 \mathrm{hPa}$ from 1 to 16 August.

The results show that large regions over West Africa were constantly influenced by recent local convection during the timeframe of the M55 campaign, making it difficult to define an "unperturbed" state in the lower TTL with respect to con-
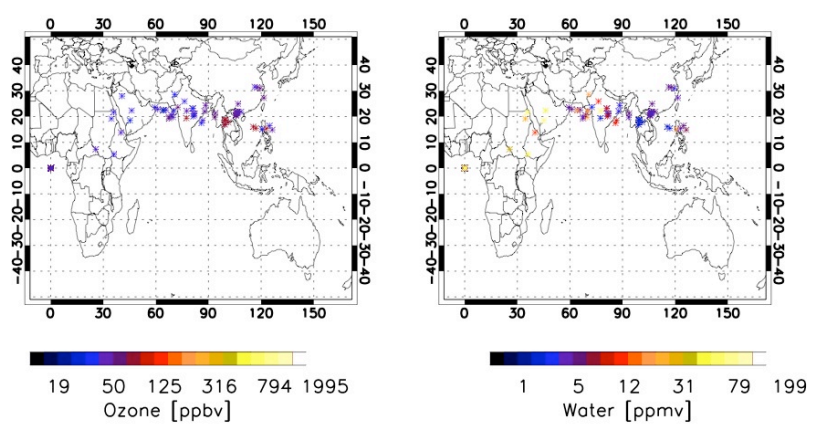

Fig. 7. Origins of M55 flight track back trajectories from below $800 \mathrm{hPa}$, colour coded in terms of ozone in ppbv (left panel) and water vapour in ppmv (right panel) observed along the flights.

vective influence at this altitude. The fraction of convectively processed air (\%) is also shown for each day in Fig. 8. This represents the fraction of trajectories that have passed over a convective system over Africa, as identified by MSG. At least $5 \%$ of trajectories need to have encountered convection in order to be included in the calculation of the average impact for each day. This provides an estimate about the regional influence of convection on different days during the campaign at the main convective outflow level $(200 \mathrm{hPa})$. The flights on 8 , 11 and 12 August were more influenced by convection compared to other days with fractions reaching $12-15 \%$. These results can be compared with estimates of local convective impact along the flight tracks also based on coincidences between back trajectories and MSG clouds (Fig. 9). The average percentage of trajectories arriving between $350-360 \mathrm{~K}$ are shown as a vertical bar since it is not possible to discriminate differences in altitude based on coincidences with MSG convective clouds. The percentages are larger than those calculated for the whole domain at $200 \mathrm{hPa}$ and can be explained by the location of particular flights and the fact that Fig. 9 also includes coincidences up to $360 \mathrm{~K}$. In general, the along flight estimates show similar variations between the different days as seen for the whole region (Fig. 8) except for 7 August which shows more convective influence in the along flight analysis. The results in Fig. 9 confirm that the flights on 8 and 11 August were most impacted by local convection. The flight on 11 August flew in the outflow of a particularly large MCS system, which developed over Niger and Nigeria. The flight on 8 August was planned as a CALIPSO validation flight but was nevertheless downwind of a large MCS which had developed further east. On 7 August, the aircraft flew in the outflow of a small MCS that tracked across Niger, Burkina Faso and Mali (Cairo et al., 2010). The fact that this was a rather small system explains the lower along flight fractions in Fig. 9 and the low average regional convective impact in Fig. 8. The flights on 4 and 13 August, when the M55 flew to south to the Gulf of Guinea, show less convective influence, particularly on 4 August. On 13 August the southern part of the flight at $200 \mathrm{hPa}$ was influenced by air 

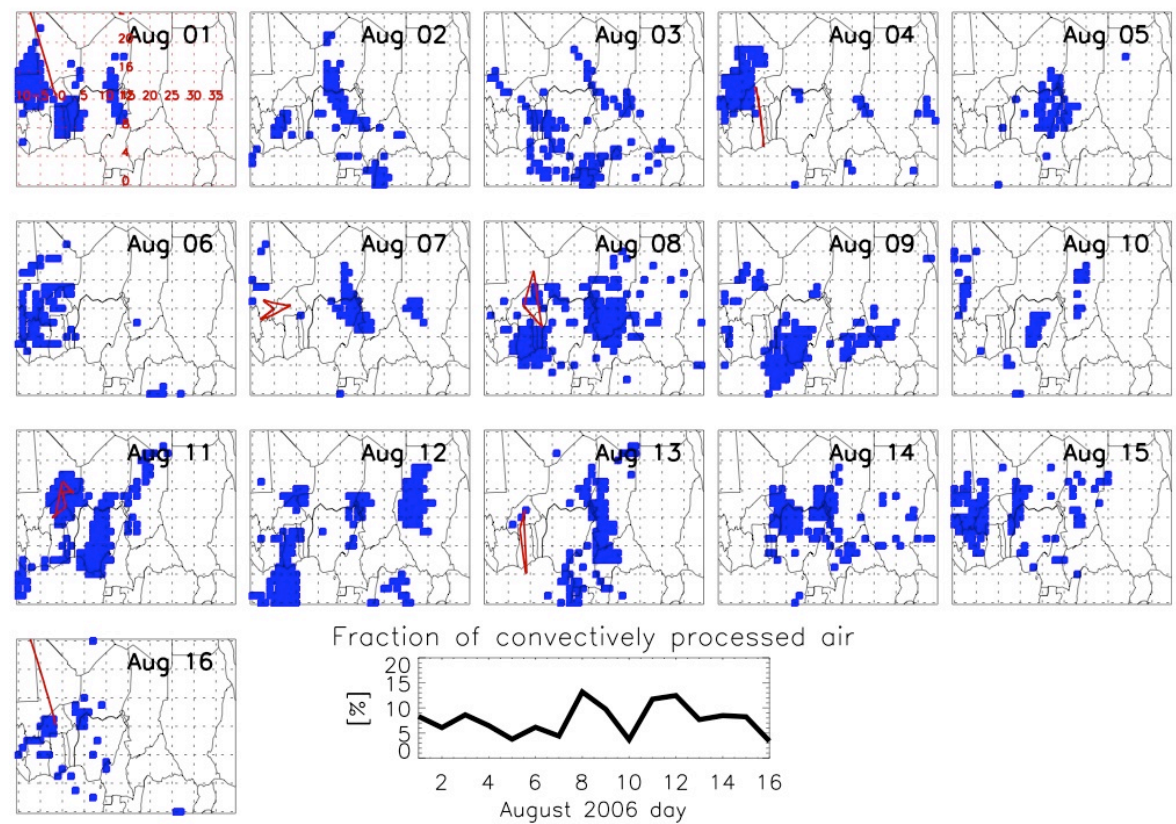

Fraction of convectively processed air

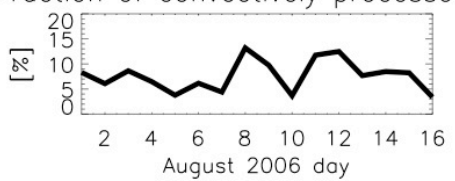

Fig. 8. Daily maps of convective impact at $200 \mathrm{hPa}$ level derived from the percentage of trajectories passing over convective systems diagnosed from MSG cloud tops over the West African domain (blue points, see text for details). M55 flight paths are displayed for the days flights took place. Also shown (inset, bottom right) is an estimate of the fraction of convectively processed air for the West African region. Only grid points where at least $5 \%$ of trajectories have been "processed" by convection were used in the calculation of the average.

masses convectively uplifted further east over central Africa (Real et al., 2010). In the case of the flight on the 4 August, it was possibly influenced by local sporadic convective near Ouagadougou, at the beginning and end of the flight.

These results can also be compared to a more detailed study described in a companion paper, Fierli et al. (2010), where a mesoscale model was used to estimate convective fractions for M55 flights on 7, 8 and 11 August 2006. The BOLAM simulations, covering the latitude band $15^{\circ} \mathrm{W}$ to $45^{\circ} \mathrm{E}$, were nudged with MSG brightness temperatures leading to a more realistic representation of convective systems during the campaign period (see also Orlandi et al., 2010). Their estimates of convective fraction (derived from model calculated tracers originating from near the surface) varied a lot between flights and with altitude. In general, Fierli et al. (2010) estimated significant convective impact over West Africa extending to higher altitudes although the results for different days are broadly consistent with the analysis presented in this paper. On 7 August around $30-40 \%$ of air masses were influenced by convection up to $355 \mathrm{~K}$. At these altitudes, estimated convective influence, based on modelled tracer results, was higher on 8 August (up to $70 \%$ ) but lower on 11 August (20-40\% locally). All flights showed some influence (10-20\% on average) at higher altitudes (370 K).
Figure 9 also compares local convective influence, based on coincidence with convective clouds, with the impact of large-scale uplift diagnosed from ECMWF trajectories along the flights. The large scale uplift was diagnosed as the percentage of 10-day back trajectories arriving in $4 \mathrm{~K}$ altitude bins between $340 \mathrm{~K}$ to $374 \mathrm{~K}$ along the M55 flights which have experienced irreversible uplift above $650 \mathrm{hPa}$ (indicative of planetary boundary layer top in ECMWF analyses). To discriminate between uplift over Africa and upwind regions the longitude where uplift occurred is also shown. Note that about 200 trajectories were run back from each flight and, as such, 30 points in Fig. 9 represent about $30-40 \%$ of the observations. The results show that as well as local convection, the flights on 7 and 8 August were also significantly influenced by large-scale uplift several days earlier over India (around $80^{\circ} \mathrm{E}$ ) and Asia $\left(100-120^{\circ} \mathrm{E}\right)$. Impacts varied from $20-40 \%$ on 7 August up to $360 \mathrm{~K}$ and reaching 60 $80 \%$ up to $360 \mathrm{~K}$ and $30 \%$ at $370 \mathrm{~K}$ on 8 August. In contrast, the 11 August flight was almost entirely influenced by local African uplift (around $40^{\circ} \mathrm{W}$ ) up to $360 \mathrm{~K}$. Interestingly, the 4 August flight, which shows little local convective influence, was influenced by large-scale uplift up to about $365 \mathrm{~K}$, again from Indian and Asian regions. The 13 August shows no impact from large-scale uplift in Fig. 9 although clear influences from the African and Asian troposphere are shown for this day in Fig. 4. This is due to the more strict criteria used to diagnose uplift ( $650 \mathrm{hPa}$ compared to the range $1000-400 \mathrm{hPa}$ in Fig. 4) and the fact that results in Fig. 9 are 

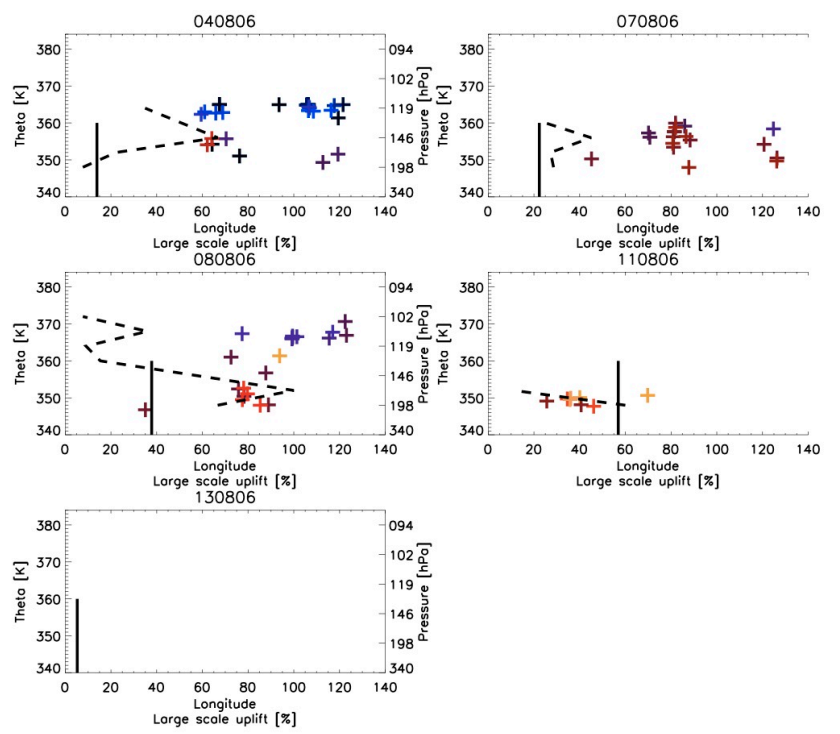

68101214161820 Latitude [ ${ }^{\circ} \mathrm{N}$ ]

Fig. 9. Fraction of air masses influenced by large-scale convective uplift $(\%)$ calculated using 10 day back trajectories arriving along M55 flights in $4 \mathrm{~K}$ bins between $340 \mathrm{~K}$ and $375 \mathrm{~K}$ over West Africa for each local M55 flight (dashed lines). Also shown are average longitudes where air masses arriving along local flights were uplifted irreversibly above $650 \mathrm{hPa}$ coloured by latitude where air masses were sampled by the M55. The average fraction of back trajectories from flight tracks between $350-360 \mathrm{~K}$ coinciding with MSG cloud tops (\%) are shown as a vertical bar as an indicator of local convective impact (see text for details).

based on along flight trajectories whereas Fig. 4 shows uplift from upwind regions into West Africa.

In summary, recent local convection appears to have had a rather significant influence on the West African region during the period of the M55 campaign in the lower TTL (based on matches with MSG convective clouds) up to an altitude of at least $365 \mathrm{~K}$ and sometimes $370 \mathrm{~K}$. In addition, the air masses sampled by the M55 were also significantly influenced by uplift of tropospheric air masses from India, Asia and oceanic regions.

\section{Relation to observed trace gas profiles}

In the following section, we examine whether distinct signatures of different air mass origins can be seen in trace gas and aerosol data that was observed by the M55 during the local flights over West Africa. The data was grouped into flights with more (7, 8, 11 August) or less (4, 13 August) influence from recent local convection over Africa. Measurements from the "convective" and "non-convective" flights are plotted as a function of theta in Fig. 10a and b. Data points are coloured by latitude and cross symbols identify measure-
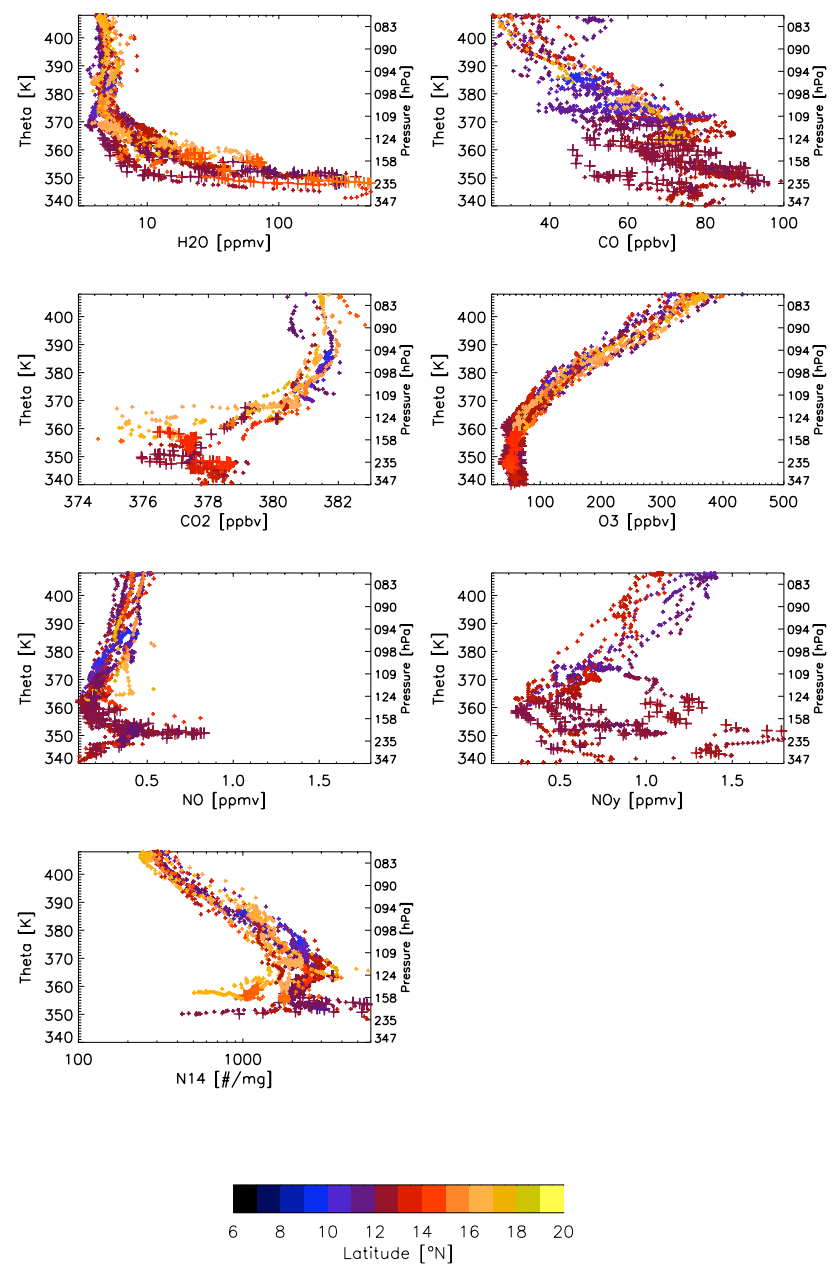

Fig. 10a. Vertical profiles of trace gas concentrations (volume mixing ratio in ppbv or ppmv as appropriate) and aerosol mass mixing ratios (particles per mg air), $\mathrm{N}_{14}(14 \mathrm{~nm}$ to $<1 \mu \mathrm{m})$, for "convective" M55 flights on 7, 8 and 11 August 2006. Profiles are plotted as a function of theta $(\mathrm{K})$ and coloured by latitude where the measurements were made. Crosses indicate points where back trajectories show uplift from below $800 \mathrm{hPa}$ during 10 days before the flight.

ments influenced by uplift, over Africa and upwind, from below $800 \mathrm{hPa}$ over the previous 10 days. Following the analysis in the previous sections, local convection over Africa had a significant impact on air masses sampled by the M55 up to $350-365 \mathrm{~K}$ and in some instances at higher altitudes (370 K). Air uplifted over upwind regions was shown to have an influence up to $370 \mathrm{~K}$ and air imported from the lower stratosphere impacted air masses between 370 and $410 \mathrm{~K}$. Signatures from these different origins are diluted to a lesser or greater degree depending on the time since transport into the TTL and the rate of mixing with surrounding air masses.

Clear signatures related to recent convection can be seen in constituents that have a short lifetime such as NO and aerosols. Observations of NO during the "convective" flights on 7 and 8 August show enhanced concentrations as high 

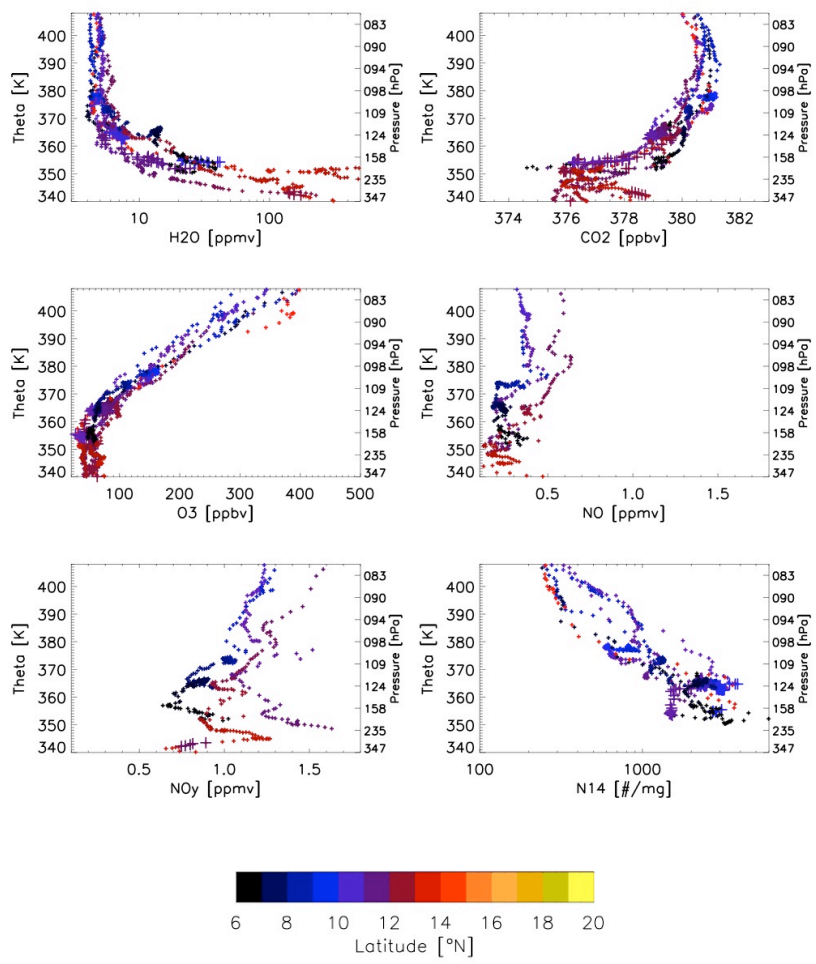

Fig. 10b. Vertical profiles of trace gas concentrations (volume mixing ratio in ppbv or ppmv as appropriate) and aerosol mass mixing ratio (particles per $\mathrm{mg}$ air), $\mathrm{N}_{14}(14 \mathrm{~nm}$ to $<1 \mu \mathrm{m}$ ), for "nonconvective" M55 flights on 4 and 13 August 2006. Profiles are plotted as a function of theta $(\mathrm{K})$ and coloured by latitude where the measurements were made. Crosses indicate points where back trajectories show uplift from below $800 \mathrm{hPa}$ during 10 days before the flight.

as 800 pptv up to $355 \mathrm{~K}$ (Fig. 10a) compared to a "nonconvective" flight on 13 August (Fig. 10b). Such enhancements strongly suggest an influence of recent convection resulting in either NO production by lightning (Höeller et al., 2009) or uplift of surface air masses impacted by soil $\mathrm{NO}_{\mathrm{x}}$ emissions. Saunois et al. (2009) and Stewart et al. (2008) report concentrations of surface $\mathrm{NO}_{\mathrm{x}}$ up to $1 \mathrm{ppbv}$ north of $10^{\circ} \mathrm{N}$ where emissions from bare soils become dominant over vegetation. Both M55 flights were made north of this latitude. Interestingly, measured NO in the "non-convective" flights shows concentrations between $200-400$ pptv up to $370 \mathrm{~K}$. The impact of $\mathrm{NO}_{\mathrm{x}}$ on photochemical $\mathrm{O}_{3}$ production is discussed later in this section. Figure 10 also shows measured $\mathrm{NO}_{\mathrm{y}}$ concentrations. There is a large variability in the profiles, especially for the "convective" flights below about $365 \mathrm{~K}$ linked to the influence of local emissions. At these altitudes, $\mathrm{NO}_{\mathrm{y}}$ is mainly expected to be in the form of $\mathrm{HNO}_{3}$ and to have a relatively long lifetime (in the absence of washout). Enhanced concentrations are also found on the "non-convective" flight days suggesting an influence

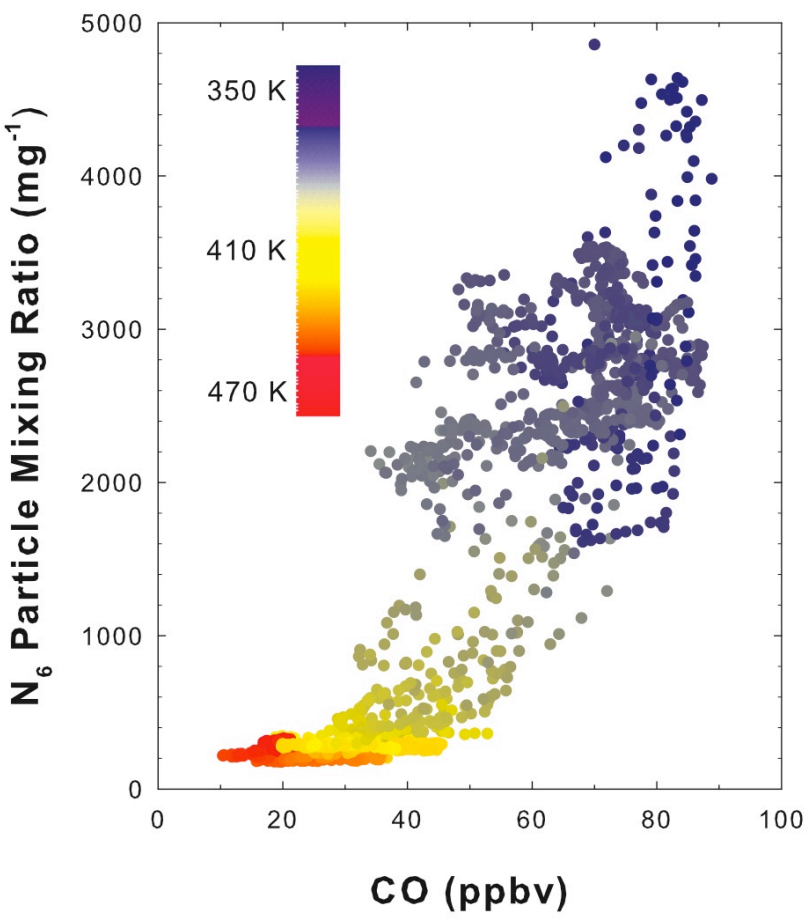

Fig. 11. Scatter plot of $\mathrm{CO}$ (ppbv) versus aerosol mass mixing ratio (greater than $6 \mathrm{~nm}$, less than $1 \mu \mathrm{m}$ ) (particles per milligram of air) for local M55 flights over West Africa coloured as a function of potential temperature $(\mathrm{K})$. Aerosol nucleation events have been removed (see text for details).

from upwind sources (lightning or anthropogenic). $\mathrm{NO}_{\mathrm{y}}$ increases above $370 \mathrm{~K}$ due to the import of LS air masses.

When looking at fine particle measurements from COPAS, which represent the total number concentration of aerosol particles per $\mathrm{mg}$ of air with sizes between $14 \mathrm{~nm}$ and roughly $1 \mu \mathrm{m}$, denoted $\mathrm{N}_{14}$, it can be seen that during August 2006, more variable aerosol concentrations were observed at $350 \mathrm{~K}$ in the "convective" flights compared to the "non-convective" flights. There also appears to be a minimum in concentrations around $355 \mathrm{~K}$ and some air masses have low aerosol below $360 \mathrm{~K}$ possibly due to washout in convective systems. In both "convective" and "non-convective" flights, concentrations decrease towards the top of the TTL $(420 \mathrm{~K})$. In the lower TTL, the origin of the aerosols is unknown but may be related to uplift of precursor emissions or recent nucleation. Figure 11 shows the correlation between fine-mode aerosols and $\mathrm{CO}$ for the 7 and 8 August with air masses influenced by recent nucleation removed. In this case, $\mathrm{N}_{6}(6 \mathrm{~nm}$ to $<1 \mu \mathrm{m})$ is plotted and the difference between $\mathrm{N}_{6}$ and $\mathrm{N}_{14}$ was used to remove nucleation events associated with recent convection (see also Borrmann et al., 2010). Figure 11 shows a clear positive correlation suggesting a common origin. This could either be from biomass burning over Asia or central Africa or from anthropogenic sources. However, Borrmann 
et al. (2010) show a minimum in the fraction of non-volatile particles between $340-370 \mathrm{~K}$. This suggests the presence of aerosols, like sulphate, which could have been transported from anthropogenic sources in Asia, rather than a biomass burning source (see also CO discussion). Interestingly, in the upper TTL, where aerosol concentrations are lower, there is a maximum (up to 50\%) in the fraction of non-volatile particles indicating the presence of non-sulphate aerosol. These air masses are more aged (see discussion about $\mathrm{CO}_{2}$ ) and may represent a residual layer of older aerosols that have not been removed by washout at lower altitudes.

$\mathrm{CO}$ was only measured during the "convective" flights on 7 and 8 August. The observations show considerable variability (45 to $100 \mathrm{ppbv}$ ) up to $370 \mathrm{~K}$ and generally decreasing concentrations above (see Fig. 10a). The range of observed $\mathrm{CO}$, which has a lifetime of 2-3 months, reflects a combination of recent inputs into the TTL and mixing with more aged air masses. Comparison with data collected in the lower troposphere can be used as an indicator of convective uplift. Over West Africa during late July/August 2006, lower tropospheric CO varied from $145 \mathrm{ppbv}$ over southern tropical forests to $80-90 \mathrm{ppbv}$ north of $14^{\circ} \mathrm{N}$ (Saunois et al., 2009; Reeves et al., 2010). An analysis of all aircraft vertical profile data collected during July-August 2006 showed a maximum in $\mathrm{CO}$ concentrations in the upper troposphere (200 hPa) (Bouarar et al., 2010) and that flights influenced by local convection had more variable $\mathrm{CO}$ ranging from 80 to $200 \mathrm{ppbv}$ compared to "non-convective" flights (100-150 ppbv). The M55 data is at the lower end of this range ( $80-100 \mathrm{ppbv}$ at $200 \mathrm{hPa})$. CO concentrations ranged between 70-90 ppbv in air masses where aerosol nucleation, likely to be associated with recent convection, was diagnosed to have taken place.

As already mentioned in Sect. 3, analysis of MLS CO data over the Tibetan plateau shows the existence of a positive $\mathrm{CO}$ anomaly up to $100 \mathrm{hPa}$ (Randel et al., 2007), with concentrations in the range $80-100$ ppbv attributed to deep convective uplift of anthropogenic and biomass burning emissions, particularly over India and south-east Asia (Park et al., 2009). Surface CO concentrations measured over Asia are highly variable and depend on whether a site is influenced by marine or polluted air masses. For example, data collected in southern Thailand shows concentrations varying from $50 \mathrm{ppbv}$ to several hundreds of ppbv (Pochanart et al., 2003). However, it does appear that uplift in the Asian summer monsoon, followed by slow ascending transport around the upper level Tibetan anticyclone leads to enhanced $\mathrm{CO}$ up to $370 \mathrm{~K}$ at this time of year. Some of this pollution is transported westward by the TEJ and contributes to enhanced $\mathrm{CO}$ over southern West Africa as seen in satellite, MOZAIC and aircraft data (Barret et al., 2008; Reeves et al., 2010). As well as CO, Park et al. (2008) also showed enhancements up to $20 \mathrm{~km}$ in trace gases measured by the ACE satellite that are markers of surface pollution such as HCN (an indicator of biomass burning) and hydrocar- bons over a region extending from $0-120^{\circ} \mathrm{E}$ and $10-40^{\circ} \mathrm{N}$ during June to August 2004-2006. However, MODIS fire count data show that biomass burning was not very prevalent during the latter half of July, or the beginning of $\mathrm{Au}$ gust in 2006 (see http://rapidfire.sci.gsfc.nasa.gov/firemaps/) suggesting that anthropogenic sources were more important. This is also supported by the fine-mode aerosol analysis discussed previously. Therefore, since $\mathrm{CO}$ concentrations in air masses originating either from local African convection or upwind convection can have similar concentrations in the TTL, it is difficult to separate these two origins using $\mathrm{CO}$ alone. The measurements of aerosols, $\mathrm{NO}_{\mathrm{y}}$ and as discussed later, $\mathrm{CO}_{2}$, support the hypothesis that the lower-mid TTL was strongly influenced by uplift of lower tropospheric air masses.

One exception is an event with very low CO concentrations ( $<50 \mathrm{ppbv})$ observed between 350 and $360 \mathrm{~K}$ that was also subject to uplift from the lower troposphere. These air masses had low $\mathrm{H}_{2} \mathrm{O}$ suggesting dehydration during transport. However, surface measurements of lower tropospheric CO over Asia reported by the United States National Oceanic and Atmospheric Administration (NOAA) Carbon Cycle Greenhouse Gas (CCGG) monitoring network (http://www.esrl.noaa.gov/gmd/ccgg/iadv/) do not show values below $50 \mathrm{ppbv}$. This, and the fact that $\mathrm{O}_{3}$ concentrations were not particularly low (50-60 ppbv), suggests that uplift from an oceanic region followed by mixing with air of lower stratospheric origin had taken place, even in the lower part of the TTL. The analysis presented in Sect. 4 suggests a low stratospheric influence of $10-20 \%$ at $350-360 \mathrm{~K}$ in the M55 flights. However, this contribution may have been underestimated in this case.

$\mathrm{CO}_{2}$ was measured during "convective" flights influenced primarily by African convection on 11 August and uplift over India on 8 August. Below $360 \mathrm{~K}$, air masses that were uplifted show variable $\mathrm{CO}_{2}$ concentrations between 375 to 379 ppmv. Flights of the DLR-Falcon (up to $200 \mathrm{hPa}$ ) found slightly enhanced $\mathrm{CO}_{2}$ concentrations (379 to $380 \mathrm{ppmv}$ ) in convectively uplifted air masses compared to more typical upper tropospheric values (374 to $376 \mathrm{ppmv}$ ) (AndrésHernández et al., 2009). Low concentrations observed up to $368 \mathrm{~K}$ on 11 August have been attributed to active local convective uplift on that day (Fierli et al., 2010; Homan et al., 2010) transporting boundary layer $\mathrm{CO}_{2}$ with low $\mathrm{CO}_{2}$ concentrations into the TTL. These air masses were associated with higher $\mathrm{H}_{2} \mathrm{O}$, some enhancement in aerosols and $\mathrm{O}_{3}$ concentrations around $60 \mathrm{ppbv}$. It is likely that daytime drawn down of $\mathrm{CO}_{2}$ over tropical forests led to lower concentrations being uplifted (Williams et al., 2001). Apart from this low $\mathrm{CO}_{2}$ event, a positive gradient in $\mathrm{CO}_{2}$ is seen in the lower and mid-TTL in these "convective" flights. Above this altitude $\mathrm{CO}_{2}$ starts to decline below the top of the TTL $(425 \mathrm{~K})$ reflecting the slow ascent of the seasonal variation of tropospheric $\mathrm{CO}_{2}$ into the stratosphere, the so-called tape recorder (Boering et al., 1996; Homan et al., 2010). The 
$\mathrm{CO}_{2}$ profiles measured on 4 and 13 August also show $\mathrm{CO}_{2}$ increasing with altitude above $350 \mathrm{~K}$ except for one low $\mathrm{CO}_{2}$ event between $360-368 \mathrm{~K}$. An event with higher $\mathrm{CO}_{2}(380-$ $381 \mathrm{ppmv}$ at $200 \mathrm{hPa}$ ) has been linked to convective uplift of central African biomass burning emissions on 13 August (black points in Fig. 10b) (see Real et al., 2010). This event, which is not diagnosed in the ECMWF trajectories, was accompanied by enhanced concentrations of $\mathrm{O}_{3}, \mathrm{NO}, \mathrm{NO}_{\mathrm{y}}$ and aerosols. A similar event was observed on 4 August in the aerosol data.

The constant perturbation of the $\mathrm{CO}_{2}$ profile by deep convection over Africa or by convective uplift to the east resulted in concentrations up to 381-382 ppmv being observed in the TTL over West Africa. Note that concentrations observed during summer 2006 at NOAA CCGG surface sites in Asia varied from 373 to $382 \mathrm{ppmv}$ (see http://www.esrl. noaa.gov/gmd/ccgg/iadv/). Measured TTL $\mathrm{CO}_{2}$ during the 8 August flight that was particularly influenced by uplift over India (see Fig. 9) was in this range. Given the long lifetime of $\mathrm{CO}_{2}$, these recent signatures are superimposed on the large-scale picture. The M55 profiles are partly in accordance with the notion of slow ascent of air masses injected several months earlier during Northern Hemisphere spring when surface $\mathrm{CO}_{2}$ concentrations are higher (e.g. Boering et al., 1996, and supported by Homan et al., 2010). However, measured profiles of $\mathrm{CO}_{2}, \mathrm{CO}$ etc. up to $370 \mathrm{~K}$ also reflect more recent origins including local (last 3-4 days) and upwind (last 10-20 days) convection. This suggests that the age spectrum of air masses in the lower and mid-TTL may include a higher component of younger air masses and depend on local convection and advection of recently uplifted air masses into the region. Previous studies estimating the age of air based on $\mathrm{CO}_{2}$ gradients in the TTL largely focused on the winter months (e.g. Park et al., 2007). However, age of air depends on seasonal variations in local convection in different regions as discussed recently by Park et al. (2010) and Gettelman et al. (2009). Our results over West Africa during Northern Hemisphere summer show that, as well as local convection associated with the African monsoon being an effective mechanism for transporting air masses up to a maximum altitude of $360-365 \mathrm{~K}$, the Asian monsoon is also effective at transporting trace gases rapidly up to $370 \mathrm{~K}$ followed by westward transport to the region.

The interpretation of the measured $\mathrm{O}_{3}$ profiles over West Africa during the M55 campaign is complicated because $\mathrm{O}_{3}$ has competing sources in the stratosphere and the lower troposphere. Analysis of tropical ozonesonde data from the SHADOZ network (e.g. Folkins et al., 2002; Thompson et al., 2007) shows the presence of an $\mathrm{O}_{3}$ minimum, varying between 30 and $60 \mathrm{ppbv}$, in the region of convective outflow $(200 \mathrm{hPa}, 350 \mathrm{~K})$. This is often explained by the uplift of $\mathrm{O}_{3}$ poor air from clean marine regions or regions with low emissions of precursors (e.g. Selkirk et al., 2010). Concentrations increase rapidly with altitude to the top of the TTL. This is attributed to an increasing contribution from import of LS air masses particularly above the cold point tropopause (e.g. Konopka et al., 2010). Previous studies have also shown significant longitudinal variations in upper tropospheric $\mathrm{O}_{3}$ related to the large scale circulation in the troposphere and lower stratosphere, leading to, for example, a maximum over the Tibetan Plateau linked to the formation of the summer Asian monsoon (Randel et al., 2007) and, the formation of a semi-permanent maximum in the UT over the southern Atlantic Ocean due to the recirculation of air masses rich in $\mathrm{O}_{3}$ from central African biomass burning regions by the Hadley circulation (e.g. Sauvage et al., 2006, Sauvage et al., 2007b). Therefore, it is clear that $\mathrm{O}_{3}$ concentrations in the TTL are variable and depend on location and time of year. In addition, $\mathrm{O}_{3}$ and its precursors such as $\mathrm{CO}$ or $\mathrm{NO}_{\mathrm{x}}$ are highly variable in the troposphere. This makes it difficult to justify the use of seasonal or annual average vertical profiles to estimate the impact of deep convection and transport into the stratosphere, as was the case in recent studies (Konopka et al., 2010; Gettelman et al., 2009).

In the lower TTL, as part of AMMA, analysis of MOZAIC and $\mathrm{MLS} \mathrm{O}_{3}$ data at $200 \mathrm{hPa}$ over western and central Africa during the summer 2006 monsoon, showed a maximum at $10^{\circ} \mathrm{S}$, a minimum at $5^{\circ} \mathrm{N}$, and increasing concentrations further north (Barret et al., 2010) giving rise to a pronounced latitudinal gradient varying from $45-50 \mathrm{ppbv}$ over the southern coast of West Africa to more than 70-80 ppbv over the Sahara. The minimum over southern West Africa is related to convective uplift of $\mathrm{O}_{3}$-poor air masses from forested regions (high $\mathrm{O}_{3}$ dry deposition, Saunois et al., 2009) or oceanic regions. Reeves et al. (2010) also noted latitudinal differences in ozonesonde data collected in July and August 2006 at Cotonou, Benin $\left(6^{\circ} \mathrm{N}, 2^{\circ} \mathrm{E}\right)$ and Niamey, Niger $\left(13^{\circ} \mathrm{N}\right.$, $2^{\circ} \mathrm{E}$ ), further north. Although minimum concentrations at $200 \mathrm{hPa}$ were slightly lower over Cotonou, a pronounced upper tropospheric maximum is present over Niamey between 450-250 hPa most likely due to photochemical production of $\mathrm{O}_{3}$ from lightning $\mathrm{NO}_{\mathrm{x}}$ emissions or from uplift of a mixture of soil $\mathrm{NO}_{\mathrm{x}}$ and biogenic hydrocarbons (advected northwards in the lower troposphere, Saunois et al., 2009).

The measured $\mathrm{M}_{5} \mathrm{O}_{3}$ profiles reflect the different combination of air mass origins as discussed already for other trace species. Whilst it is difficult to generalise, the "convective" profiles (Fig. 10a), which were primarily collected north of $10^{\circ} \mathrm{N}$, generally have higher $\mathrm{O}_{3}$ concentrations at $350-360 \mathrm{~K}$ than the "non-convective" profiles (Fig. 10b) which include descents to $350 \mathrm{~K}(200 \mathrm{hPa})$ at $5^{\circ} \mathrm{N}$ and have lower concentrations. The M55 data are within the range measured by the DLR Falcon during the same period (Andrés-Hernández et al., 2009) up to $150 \mathrm{hPa}$. They also found evidence for higher $\mathrm{O}_{3}$ concentrations in regions of convective outflow coincident with elevated levels of $\mathrm{O}_{3}$ precursors from lightning $\mathrm{NO}_{\mathrm{x}}$ emissions and surface uplift as mentioned previously. 


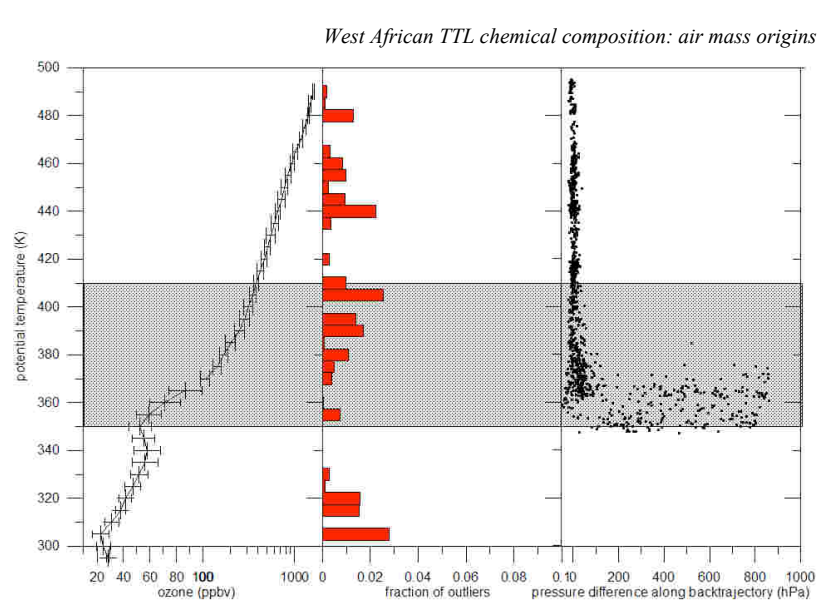

Fig. 12. Leftmost profile, average ozone concentrations (ppbv) using M55 data collected south of $17.5^{\circ} \mathrm{N}$ versus potential temperature $(\mathrm{K})$, bars denote one standard deviation; note the linear $(<100 \mathrm{ppbv}) / \log (>100 \mathrm{ppbv})$ horizontal axis for ozone. Middle bar chart, fraction of ozone data points lying outside three standard deviations from the mean, versus potential temperature; Rightmost panel, pressure difference $(\mathrm{hPa})$ along 10-day back trajectories arriving along M55 flights (south of $17.5^{\circ} \mathrm{N}$ ) versus potential temperature $(\mathrm{K})$. Grey shading denotes the main TTL region.

Figure 12 shows the average $\mathrm{O}_{3}$ profile as a function of potential temperature, using data from all local flights, together with the fraction of data points lying three standard deviations outside the mean. As discussed above, the lower part of the ozone profile can be understood in terms of local recent deep convection with a local maximum at $340 \mathrm{~K}$ and a weak minimum at $350 \mathrm{~K}$. In the lower TTL, $\mathrm{O}_{3}$ concentrations increase but at a slower rate than above $370 \mathrm{~K}$ (roughly 2 ppbv per K below $370 \mathrm{~K}$ and 6 ppbv per $\mathrm{K}$ above $370 \mathrm{~K})$. This is due to the important contribution from uplift of tropospheric air masses as confirmed by the pressure variations along the back trajectories (rightmost panel in Fig. 12) as well as enhanced variability in the $\mathrm{O}_{3}$ data up to $370 \mathrm{~K}$. Average concentrations in the lower TTL are also below $100 \mathrm{ppbv}$, again indicating the importance of uplift of tropospheric air masses. Above $370 \mathrm{~K}, \mathrm{O}_{3}$ concentrations are higher at this time of year compared to measurements made at other times of year at other tropical locations due to seasonal variations in lower stratospheric temperatures and stratospheric up-welling (Randel et al., 2007; Homan et al., 2010) and the important contribution from LS import via the Asian monsoon anticylone as shown in this study and by others (e.g. Konopka et al., 2010).

The data presented here show that the M55 observed non-negligible concentrations of $\mathrm{NO}$ and $\mathrm{CO}$ up to $370 \mathrm{~K}$ suggesting that the lower TTL is potentially more photochemically active than previously assumed, and that the Asian and African monsoons provide an important mechanism for transporting pollutants into this region. Real et al. (2010) used a photochemical trajectory model initialised with AMMA data (for the biomass burning plume case on 13 August 2006) to calculate rates of in-situ net $\mathrm{O}_{3}$ photochemical production, $\mathrm{NPO}_{3}$, downwind from West Africa in the upper troposphere. They found that slow but positive $\mathrm{NPO}_{3}$ (in runs with and without mixing with surrounding air masses) can be maintained even in air masses with NO concentrations of $200 \mathrm{pptv}$. Here, we performed further runs of the CiTTyCAT photochemical model taking initial conditions of $\mathrm{O}_{3}$ precursors such as VOCs and $\mathrm{NO}_{\mathrm{y}}$ species from the background conditions in the upper tropospheric case of Real et al. (2010). CO was initialised at 90 ppbv based on M55 data. The model was run for 4 days at $150 \mathrm{hPa}$ and average $\mathrm{NPO}_{3}$ calculated over the last $24 \mathrm{~h}$. Mixing was not taken into account in the simulations. A series of sensitivity tests were carried out varying initial concentrations of $\mathrm{O}_{3}, \mathrm{H}_{2} \mathrm{O}$ and $\mathrm{O}_{3}$ precursors (NO, CO and VOCs). As already discussed in Real et al. (2010), $\mathrm{NPO}_{3}$ was quite insensitive to initial $\mathrm{CO}$ and VOC concentrations. The sensitivity of $\mathrm{NPO}_{3}$ to initial NO, $\mathrm{O}_{3}$ and $\mathrm{H}_{2} \mathrm{O}$ concentrations is shown in Fig. 13. NO concentrations were varied but concentrations of other $\mathrm{NO}_{\mathrm{y}}$ species were kept the same totalling around 300 pptv (not including NO).

At $\mathrm{O}_{3}$ concentrations below 150 ppbv $\mathrm{NPO}_{3}$ is always positive and varies from about $0.5 \mathrm{ppbv}$ per day to more than 2 ppbv per day with higher $\mathrm{NPO}_{3}$ at higher $\mathrm{NO}$ and higher $\mathrm{H}_{2} \mathrm{O} . \mathrm{H}_{2} \mathrm{O}$ and $\mathrm{O}^{1} \mathrm{D}$ from $\mathrm{O}_{3}$ photolysis react to produce $\mathrm{OH}$, and therefore $\mathrm{HO}_{2}$ which, in the presence of $\mathrm{NO}$, leads to $\mathrm{O}_{3}$ production. At higher $\mathrm{O}_{3}$ concentrations of around 150 ppbv and low $\mathrm{NO}, \mathrm{O}_{3}$ destruction starts to dominate due to increased loss via $\mathrm{H}_{2} \mathrm{O}$ plus $\mathrm{O}^{1} \mathrm{D}$. This leads to net $\mathrm{O}_{3}$ destruction at higher $\mathrm{O}_{3}$ and low $\mathrm{NO}$ but still net $\mathrm{O}_{3}$ production at higher NO concentrations. In the lower TTL, air masses influenced by convection have higher NO than used here ( 800 pptv) which will lead to higher $\mathrm{NPO}_{3}$ (up to several ppbv per day). In the upper TTL, $\mathrm{H}_{2} \mathrm{O}$ is low but $\mathrm{NO}$ is also around 200 to 400 pptv (see Fig. 10b) and $\mathrm{O}_{3}$ is increasing leading to small but positive $\mathrm{NPO}_{3}$ of up to 0.5 ppbv per day. Thus, it is possible that much of the TTL over West Africa, and especially the lower TTL, is photochemically active and in a net $\mathrm{O}_{3}$ production regime.

Therefore, in contrast to certain studies, such as Konopka et al. (2010), which assume that tropospheric photochemisty is not important in the TTL, the results presented here, and those previously reported (e.g. Folkins et al., 2002), show that photochemistry does play an important role in governing the $\mathrm{O}_{3}$ budget, especially in the lower to mid TTL. The $\mathrm{O}_{3}$ gradient seen in the M55 observations (Fig. 12) below $370 \mathrm{~K}$ can be explained by uplift of precursors into this region, and maintenance of $\mathrm{O}_{3}$ concentrations by in-situ photochemical $\mathrm{O}_{3}$ production. Ideally, budget calculations need to be performed with global models including both tropospheric and stratospheric chemistry. Previous studies of the tropospheric $\mathrm{O}_{3}$ budget have already shown that results are very sensitive to the amount of $\mathrm{O}_{3}$ transported into the troposphere from the 


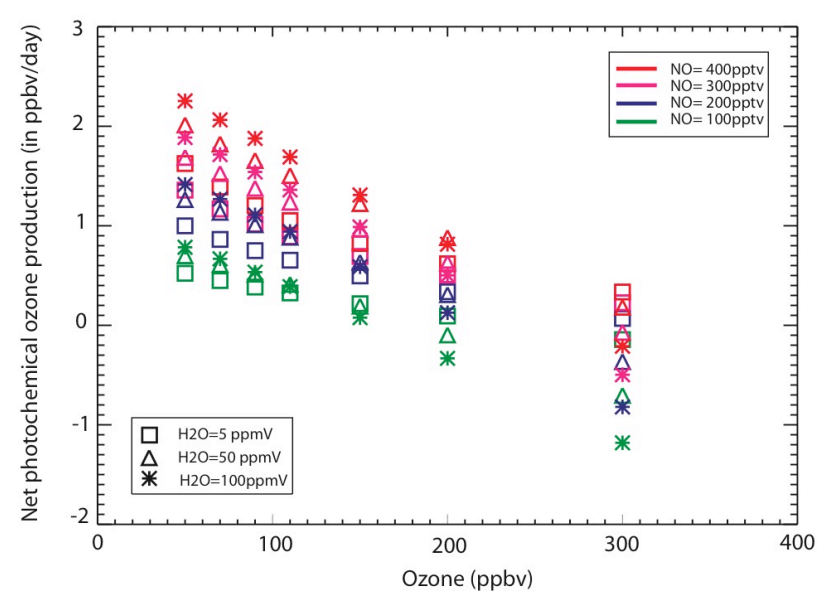

Fig. 13. TTL net photochemical $\mathrm{O}_{3}$ production rates (ppbv per day) versus initial ozone concentrations (ppbv) as a function of initial $\mathrm{H}_{2} \mathrm{O}$ concentrations (ppmv, symbols - see inset) and NO concentrations (pptv, colours as indicated). Results from photochemical model simulations run for 4 days at $150 \mathrm{hPa}$ and initialised with concentrations taken from aircraft observations in the upper troposphere. Net photochemical $\mathrm{O}_{3}$ production rates are averages over the last $24 \mathrm{~h}$. See text for further details.

stratosphere (Wu et al., 2007), and often gradients of trace species are smeared out. If global models overestimate $\mathrm{O}_{3}$ in the TTL, they are likely to underestimate $\mathrm{NPO}_{3}$ in this region, especially if $\mathrm{H}_{2} \mathrm{O}$ is also overestimated (as shown by Fig. 13). In addition, lightning $\mathrm{NO}_{\mathrm{x}}$ may be underestimated in global models as shown by Barret et al. (2010) over West Africa.

In summary, trace gas and aerosol profiles measured on the M55 during August 2006 show distinct signatures of recent local convection up to $350-365 \mathrm{~K}$, particularly in species like $\mathrm{NO}, \mathrm{CO}$ and aerosols which have shorter lifetimes relative to $\mathrm{CO}_{2}$. Signatures due to uplift over upwind regions are also evident up to $370 \mathrm{~K}$ and superimposed on features related to longer timescale variations. This is particularly true for longer-lived species like $\mathrm{O}_{3}, \mathrm{NO}_{\mathrm{y}}$ and $\mathrm{CO}_{2}$.

\section{Conclusions}

The SCOUT-AMMA M55 aircraft campaign was one of the first campaigns to take place in the Northern Hemisphere summer in a region influenced by both the African and Asian monsoons. In the analysis presented here, reverse domainfilling trajectories over West Africa and in the region of the flights, as well as back trajectories along the M55 flights, have been used to diagnose the origin of air masses influencing the TTL during first half of August 2006. Most of the air arriving over West Africa was already residing in the tropical upper troposphere and lower stratosphere. However, superimposed upon this were important contributions from local recent convection over Africa, uplift of tropospheric air masses over Asia, India, and oceanic regions as well as transport of air masses from the lower stratosphere during the 10 days before the measurements were made.

Local convective influence was found to be important in the lower TTL, and to have an influence on measured trace gas and aerosol profiles up to an altitude of 360-365 K, with the main influence at $350 \mathrm{~K}(200 \mathrm{hPa}, 12.5 \mathrm{~km})$ at convective outflow. Estimates based on reverse domain filling back trajectories originating from $1000-400 \mathrm{hPa}$ in the African lower and mid troposphere suggest an impact of around 52\% from local convection during the campaign period. Convective fractions estimated using trajectories along flight tracks show significant variability between flights with the 8 and $11 \mathrm{Au}-$ gust most influenced by convection. Estimates derived from coincidences with MSG cloud tops show similar variability but fractions are lower (10-15\%) because they are averages over a region and reflect the fact that certain flights targeted convective systems. The higher estimates, based on back trajectories are generally consistent with results from Fierli et al. (2010) who found contributions as high as 50-70\% below $355 \mathrm{~K}$ and, locally during certain flights, as high as $40 \%$ up to $370 \mathrm{~K}(100 \mathrm{hPa}, 16.5 \mathrm{~km})$. Whilst, these results highlight the need to use a variety of approaches to estimate convective impacts on the TTL, they do show that the M55 flights on 7, 8 and 11 August were more influenced by local African convection. This allowed separation of chemical and aerosol data into "convective" and "non-convective" flights. The "convective" flights exhibited more variability and, in the case of certain species, pronounced features in the lower TTL linked to local deep convection such as enhanced NO due to lightning emissions or uplift of soil $\mathrm{NO}_{\mathrm{x}}$ emissions.

Air masses in the mid-TTL over West Africa (150$100 \mathrm{hPa}, 14-16.5 \mathrm{~km}$ or $355-370 \mathrm{~K}$ ) were also significantly impacted by uplift of tropospheric air masses with differing trace gas signatures ranging from clean air (low $\mathrm{O}_{3}$, low $\mathrm{CO}$, high $\mathrm{H}_{2} \mathrm{O}$ ) to air masses likely to have been influenced by pollution over Asia or India containing higher $\mathrm{O}_{3}, \mathrm{CO}, \mathrm{CO}_{2}$ and $\mathrm{NO}_{\mathrm{y}}$. Around $40 \%$ of air masses at $355 \mathrm{~K}$ and $20 \%$ of air masses at $370 \mathrm{~K}$ may have been affected by such injection from the mid and lower troposphere. At $370 \mathrm{~K}$, there was also an important contribution from air masses advected from the mid-latitude lower stratosphere (41\%) although the M55 appears to have under-sampled this source $(21 \%)$ suggesting that the lower stratospheric fractions estimated by Homan et al. (2010) may be a lower limit. The estimates of Indian and Asian uplift in this study may also be a lower limit due the use of large-scale analyses to calculate back trajectories in regions influenced by deep convection associated with the monsoon. This may also lead to an underestimation of the altitude to which deep convection can have an impact.

Overall, the lower TTL over West Africa appears to have been significantly impacted by the upward transport of tropospheric air masses related to the Asian and African summer monsoons. In the case of Asian uplift this results in the 
transport of trace gases, and possibly aerosols, directly into the lower and mid-TTL. This suggests that air in the midTTL may have a larger component of younger air than previously estimated. The mean $\mathrm{O}_{3}$ profile appears to be affected by these transport processes leading to a less steep gradient in the lower-mid TTL and higher concentrations than seen at tropical locations away from the influence of the Asian or African monsoons. Analysis of the observed profiles together with photochemical model calculations suggests that the lower TTL is photochemically active even at background levels of $\mathrm{NO}_{\mathrm{x}}$ leading to positive net photochemical $\mathrm{O}_{3}$ production. In particular, in the lower TTL higher $\mathrm{H}_{2} \mathrm{O}$ and $\mathrm{NO}_{\mathrm{x}}$ related to convection can lead to enhanced $\mathrm{O}_{3}$ production. It remains a challenge for global models to reproduce the vertical structure of trace gases and aerosols observed in the TTL.

Acknowledgements. The M55-Geophysica SCOUT-AMMA campaign in West Africa was funded by the Geophysica EEIG, French CNRS-INSU/CNES and European Community sixth framework integrated projects SCOUT-O3 (505390-GOCE-CT-2004) and AMMA-EU. The authors also wish to acknowledge the contribution and help of Burkinabé institutes and scientists in the organisation and execution of the M55 aircraft campaign. Based on a French initiative, AMMA was built by an international scientific group and funded by a large number of agencies, especially from France, UK, US and Africa. It has been the beneficiary of a major financial contribution from the European Community's Sixth Framework Research Programme. Detailed information on scientific coordination and funding is available on the AMMA International web site http://www.amma-international.org. Scientists from ISAC-CNR acknowledge partial support from Dipartimento Terra ed Ambiente, National Research Council.

\section{Edited by: T. Bertram}

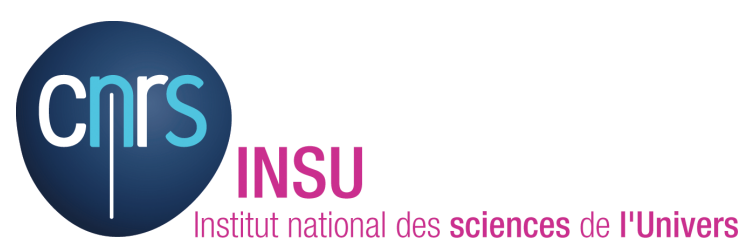

The publication of this article is financed by CNRS-INSU.

\section{References}

Adriani, A., M. Viterbini, F. Cairo, S. Mandolini, and G. Di Donfrancesco, Multiwavelength Aerosol Scatterometer for airborne experiments to study the stratospheric particle optical properties, J. Atmos. Ocean. Tech., 16, 1328-1335, 1999.

Andrés-Hernndez, M. D., Kartal, D., Reichert, L., Burrows, J. P., Meyer Arnek, J., Lichtenstern, M., Stock, P., and Schlager, H.: Peroxy radical observations over West Africa during AMMA 2006: photochemical activity in the outflow of convective systems, Atmos. Chem. Phys., 9, 3681-3695, doi:10.5194/acp-93681-2009, 2009.
Barret, B., Ricaud, P., Mari, C., Attié, J.-L., Bousserez, N., Josse, B., Le Flochmoën, E., Livesey, N. J., Massart, S., Peuch, V.H., Piacentini, A., Sauvage, B., Thouret, V., and Cammas, J.P.: Transport pathways of $\mathrm{CO}$ in the African upper troposphere during the monsoon season: a study based upon the assimilation of spaceborne observations, Atmos. Chem. Phys., 8, 3231-3246, doi:10.5194/acp-8-3231-2008, 2008.

Barret, B., Williams, J. E., Bouarar, I., Yang, X., Josse, B., Law, K. Pham, M., Le Flochmoën, E., Liousse, C., Peuch, V. H., Carver, G. D., Pyle, J. A., Sauvage, B., van Velthoven, P., Schlager, H., Mari, C., and Cammas, J.-P.: Impact of West African Monsoon convective transport and lightning NOx production upon the upper tropospheric composition: a multi-model study, Atmos. Chem. Phys., 10, 5719-5738, doi:10.5194/acp-10-57192010, 2010.

Boering, K. A., Wofsy, S. C., Daube, B. C., Schneider, H. R., Loewenstein, M., and Podolske, J. R.: Stratospheric mean ages and transport rates from observations of carbon dioxide and nitrous oxide, Science, 274(5291), 1340-1343, 1996.

Borrmann, S., Kunkel, D., Weigel, R., Minikin, A., Deshler, T., Wilson, J. C., Curtius, J., Volk, C. M., Homan, C. D., Ulanovsky, A., Ravegnani, F., Viciani, S., Shur, G. N., Belyaev, G. V., Law, K. S., and Cairo, F.: Aerosols in the tropical and subtropical UT/LS: in-situ measurements of submicron particle abundance and volatility, Atmos. Chem. Phys., 10, 5573-5592, doi:10.5194/acp-10-5573-2010, 2010.

Bouarar, I., Law, K. S., Pham, M., Hourdin, F., Szopa, S., Schlager, H., Hamburger, T., Ravegnani, F., Nédéléc, P., Liousse, C., Thouret, V., and Reeves, C. E.: Emission sources contributing to tropospheric ozone over Equatorial Africa during the summer monsoon, to be submitted Atmos. Chem. Phys. Discuss., submitted, 2010.

Brock, C., Hamill, P., Wilson, J., Jonsson, H., and Chan, K.: Particle Formation in the Upper Tropical Troposhere - A Source of Nuclei for the Stratospheric Aerosol, Science, 270, 1650-1653, 1995.

Brunner, D., Siegmund, P., May, P. T., Chappel, L., Schiller, C., Müller, R., Peter, T., Fueglistaler, S., MacKenzie, A. R., Fix, A., Schlager, H., Allen, G., Fjaeraa, A. M., Streibel, M., and Harris, N. R. P.: The SCOUT-O3 Darwin Aircraft Campaign: rationale and meteorology, Atmos. Chem. Phys., 9, 93-117, doi:10.5194/acp-9-93-2009, 2009.

Cairo, F., Pommereau, J. P., Law, K. S., Schlager, H., Garnier, A., Fierli, F., Ern, M., Streibel, M., Arabas, S., Borrmann, S., Berthelier, J. J., Blom, C., Christensen, T., D’Amato, F., Di Donfrancesco, G., Deshler, T., Diedhiou, A., Durry, G., Engelsen, O., Goutail, F., Harris, N. R. P., Kerstel, E. R. T., Khaykin, S., Konopka, P., Kylling, A., Larsen, N., Lebel, T., Liu, X., MacKenzie, A. R., Nielsen, J., Oulanowski, A., Parker, D. J., Pelon, J., Polcher, J., Pyle, J. A., Ravegnani, F., Rivière, E. D., Robinson, A. D., Röckmann, T., Schiller, C., Simões, F., Stefanutti, L., Stroh, F., Some, L., Siegmund, P., Sitnikov, N., Vernier, J. P., Volk, C. M., Voigt, C., von Hobe, M., Viciani, S., and Yushkov, V.: An introduction to the SCOUT-AMMA stratospheric aircraft, balloons and sondes campaign in West Africa, August 2006: rationale and roadmap, Atmos. Chem. Phys., 10, 2237-2256, doi:10.5194/acp-10-2237-2010, 2010.

Fierli, F., Orlandi, E., Law, K. S., Cagnazzo, C., Cairo, F., Schiller, C., Borrmann, S., Didonfrancesco, G., Ravegnani, F., and Volk, 
M.: Impact of deep convection in the tropical tropopause layer in West Africa: in-situ observations and mesoscale modelling, Atmos. Chem. Phys. Discuss., 10, 4927-4961, doi:10.5194/acpd10-4927-2010, 2010.

Folkins, I., Braun, C., Thompson, A. M., and Witte, J.: Tropical ozone as an indicator of deep convection, J. Geophys. ResAtmos., 107(D13), 4184, doi:10.1029/2001JD001178, 2002.

Fueglistaler, S., Dessler, A. E., Dunkerton, T. J., Folkins, I., Fu, Q., and Mote, P. W.: The tropical tropopause layer, Rev. Geophys., 47, 8755-1209, doi:10.1029/2008RG000267, 2009.

Gettelman, A., Forster, P. M. deF., Fujiwara, M., Fu, Q., Vomel, H., Gohar, L. K., Johanson, C., and Ammerman, M.: Radiation balance of the tropical tropopause layer, J. Geophys. Res., 109, D07103, doi:10.1029/2003JD004190, 2004.

Gettelman, A., Lauritzen, P. H., Park, M., and Kay, J. E.: Processes regulating short-lived species in the tropical tropopause, J. Geophys. Res., 114, D13303, doi:10.1029/2009JD011785, 2009.

Höller, H., Betz, H.-D., Schmidt, K., Calheiros, R. V., May, P., Houngninou, E., and Scialom, G.: Lightning characteristics observed by a VLF/LF lightning detection network (LINET) in Brazil, Australia, Africa and Germany, Atmos. Chem. Phys., 9, 7795-7824, doi:10.5194/acp-9-7795-2009, 2009.

Homan, C. D., Volk, C. M., Kuhn, A. C., Werner, A., Baehr, J., Viciani, S., Ulanovski, A., and Ravegnani, F.: Tracer measurements in the tropical tropopause layer during the AMMA/SCOUTO3 aircraft campaign, Atmos. Chem. Phys., 10, 3615-3627, doi:10.5194/acp-10-3615-2010, 2010.

Huntrieser, H., Schumann, U., Schlager, H., Höller, H., Giez, A., Betz, H.-D., Brunner, D., Forster, C., Pinto Jr., O., and Calheiros, R.: Lightning activity in Brazilian thunderstorms during TROCCINOX: implications for $\mathrm{NO}_{\mathrm{x}}$ production, Atmos. Chem. Phys., 8, 921-953, doi:10.5194/acp-8-921-2008, 2008.

Khaykin, S., Pommereau, J.-P., Korshunov, L., Yushkov, V., Nielsen, J., Larsen, N., Christensen, T., Garnier, A., Lukyanov, A., and Williams, E.: Hydration of the lower stratosphere by ice crystal geysers over land convective systems, Atmos. Chem. Phys., 9, 2275-2287, doi:10.5194/acp-9-2275-2009, 2009.

Konopka, P., Grooss, J. U., Ploger, F., and Muller, R.: Annual cycle of horizontal in-mixing into the lower tropical stratosphere, J. Geophys. Res., 114, 148-227, doi:10.1029/2009JD011955, 2009.

Konopka, P., Grooß, J.-U., Günther, G., Ploeger, F., Pommrich, R., Müller, R., and Livesey, N.: Annual cycle of ozone at and above the tropical tropopause: observations versus simulations with the Chemical Lagrangian Model of the Stratosphere (CLaMS), Atmos. Chem. Phys., 10, 121-132, doi:10.5194/acp-10-121-2010, 2010.

James, R., Bonazzola, M., Legras, B., Surbled, K., and Fueglistaler, S.: Water vapor transport and dehydration above convective outflow during Asian monsoon, Geophys. Res. Lett., 35(20), L20810, doi:10.1029/2008GL035441, 2008.

Janicot, S., Thorncroft, C. D., Ali, A., Asencio, N., Berry, G., Bock, O., Bourles, B., Caniaux, G., Chauvin, F., Deme, A., Kergoat, L., Lafore, J.-P., Lavaysse, C., Lebel, T., Marticorena, B., Mounier, F., Nedelec, P., Redelsperger, J.-L., Ravegnani, F., Reeves, C. E., Roca, R., de Rosnay, P., Schlager, H., Sultan, B., Tomasini, M., Ulanovsky, A., and ACMAD forecasters team: Large-scale overview of the summer monsoon over West Africa during the AMMA field experiment in 2006, Ann. Geophys., 26, 2569
2595, doi:10.5194/angeo-26-2569-2008, 2008.

Marcy, T. P., Popp, P. J., Gao, R. S., et al.: Measurements of trace gases in the tropical tropopause layer, Atmos. Environ., 41, 7253-7261, doi:10.1016/j.atmosenv.2007.05.032, 2007.

Mari, C. H., Cailley, G., Corre, L., Saunois, M., Attié, J. L., Thouret, V., and Stohl, A.: Tracing biomass burning plumes from the Southern Hemisphere during the AMMA 2006 wet season experiment, Atmos. Chem. Phys., 8, 3951-3961, doi:10.5194/acp-8-3951-2008, 2008.

Orlandi, E., Fierli, F., Davolio, S., Buzzi, A., and Drofa, O.: A nudging scheme to assimilate satellite brightness temperature in a meteorological model: Impact on representation of African mesoscale convective systems, Q. J. Roy. Meteorol. Soc., 136(647), 462-474, 2010.

O'Sullivan, D. and Dunkerton, T. J.: The influence of the quasibiennial oscillation on global constituent distributions, J. Geophys. Res., 102(D18), 21731-21743, 1997.

Park, M., Randel, W. J., Emmons, L. K., Bernath, P. F., Walker, K. A., and Boone, C. D.: Chemical isolation in the Asian monsoon anticyclone observed in Atmospheric Chemistry Experiment (ACE-FTS) data, Atmos. Chem. Phys., 8, 757-764, doi:10.5194/acp-8-757-2008, 2008.

Park, M., Randel, W. J., Emmons, L. K., and Livesey, N. J.: Transport pathways of carbon monoxide in the Asian summer monsoon diagnosed from Model of Ozone and Related Tracers (MOZART), J. Geophys. Res., 114, D08303, doi:10.1029/2008JD010621, 2009.

Park, S., Jiménez, R., Daube, B. C., Pfister, L., Conway, T. J., Gottlieb, E. W., Chow, V. Y., Curran, D. J., Matross, D. M., Bright, A., Atlas, E. L., Bui, T. P., Gao, R.-S., Twohy, C. H., and Wofsy, S. C.: The $\mathrm{CO}_{2}$ tracer clock for the Tropical Tropopause Layer, Atmos. Chem. Phys., 7, 3989-4000, doi:10.5194/acp-7-39892007, 2007.

Park, S., Atlas, E. L., Jiménez, R., Daube, B. C., Gottlieb, E. W., Nan, J., Jones, D. B. A., Pfister, L., Conway, T. J., Bui, T. P., Gao, R.-S., and Wofsy, S. C.: Vertical transport rates and concentrations of $\mathrm{OH}$ and $\mathrm{Cl}$ radicals in the Tropical Tropopause Layer from observations of $\mathrm{CO}_{2}$ and halocarbons: implications for distributions of long- and short-lived chemical species, Atmos. Chem. Phys., 10, 6669-6684, doi:10.5194/acp-10-66692010, 2010.

Pickering, K. E., Thompson, A. M., Tao, W. K., McNamara, D. P., Kirchhoff, V. W. J. H., Heikes, B. G., Sachse, G. W., Bradshaw, J. D., Gregory, G. L., and Blake, D. R.: Convective transport of biomass burning emissions over Brazil during TRACE A, J. Geophys. Res., 101(D19), 23993-24012, 1996.

Pochanart, P., Akimoto, H., Kajii, Y., and Sukasem, P.: Carbon monoxide, regional-scale transport, and biomass burning in tropical continental Southeast Asia: Observations in rural Thailand, J. Geophys. Res., 108, 4552, doi:10.1029/2002JD003360, 2003.

Pommereau, J.-P., Garnier, A., Held, G., Gomes, A.-M., Goutail, F., Durry, G., Borchi, F., Hauchecorne, A., Montoux, N., Cocquerez, P., Letrenne, G., Vial, F., Hertzog, A., Legras, B., Pisso, I., Pyle, J. A., Harris, N. R. P., Jones, R. L., Robinson, A., Hansford, G., Eden, L., Gardiner, T., Swann, N., Knudsen, B., Larsen, N., Nielsen, J., Christensen, T., Cairo, F., Pirre, M., Marcal, V., Huret, N., Rivire, E., Coe, H., Grosvenor, D., Edvarsen, K., Di Donfrancesco, G., Ricaud, P., Berthelier, J.-J., Godefroy, M., Seran, E., Longo, K., and Freitas, S.: An overview of the HIBIS- 
CUS campaign, Atmos. Chem. Phys. Discuss., 7, 2389-2475, doi:10.5194/acpd-7-2389-2007, 2007.

Randel, W. J., Park, M. J., Wu, F., and Livesey, N.: A large annual cycle in ozone above the tropical tropopause linked to the Brewer-Dobson circulation, J. Atmos. Sci., 64, 4479-4488, doi:10.1175/2007JAS2409.1, 2007.

Real, E., Orlandi, E., Law, K. S., Fierli, F., Josset, D., Cairo, F., Schlager, H., Borrmann, S., Kunkel, D., Volk, C. M., McQuaid, J. B., Stewart, D. J., Lee, J., Lewis, A. C., Hopkins, J. R., Ravegnani, F., Ulanovski, A., and Liousse, C.: Cross-hemispheric transport of central African biomass burning pollutants: implications for downwind ozone production, Atmos. Chem. Phys., 10, 3027-3046, doi:10.5194/acp-10-3027-2010, 2010.

Reeves, C. E., Formenti, P., Afif, C., Ancellet, G., Attié, J.-L., Bechara, J., Borbon, A., Cairo, F., Coe, H., Crumeyrolle, S., Fierli, F., Flamant, C., Gomes, L., Hamburger, T., Jambert, C., Law, K. S., Mari, C., Jones, R. L., Matsuki, A., Mead, M. I., Methven, J., Mills, G. P., Minikin, A., Murphy, J. G., Nielsen, J. K., Oram, D. E., Parker, D. J., Richter, A., Schlager, H., Schwarzenboeck, A., and Thouret, V.: Chemical and aerosol characterisation of the troposphere over West Africa during the monsoon period as part of AMMA, Atmos. Chem. Phys., 10, 7575-7601, doi:10.5194/acp-10-7575-2010, 2010.

Saunois, M., Reeves, C. E., Mari, C. H., Murphy, J. G., Stewart, D. J., Mills, G. P., Oram, D. E., and Purvis, R. M.: Factors controlling the distribution of ozone in the West African lower troposphere during the AMMA (African Monsoon Multidisciplinary Analysis) wet season campaign, Atmos. Chem. Phys., 9, 61356155, doi:10.5194/acp-9-6135-2009, 2009.

Sauvage, B., Thouret, V., Thompson, A. M., Witte, J. C., Cammas, J. P., Nedelec, P., and Athier, G.: Enhanced view of the "tropical Atlantic ozone paradox" and "zonal wave one" from the in situ MOZAIC and SHADOZ data, J. Geophys. Res., 111, D01301, doi:10.1029/2005JD006241, 2006.

Sauvage, B., Martin, R. V., van Donkelaar, A., and Ziemke, J. R.: Quantification of the factors controlling tropical tropospheric ozone and the South Atlantic maximum, J. Geophys. Res., 112, D11309, doi:10.1029/2006JD008008, 2007a.

Sauvage, B., Thouret, V., Cammas, J. P., Brioude, J., Nedelec, P., and Mari, C.: Meridional ozone gradients in the African upper troposphere, Geophys. Res. Lett., 34(3), L03817, doi:10.1029/2006GL028542, 2007b.

Schiller, C., Grooß, J.-U., Konopka, P., Plöger, F., Silva dos Santos, F. H., and Spelten, N.: Hydration and dehydration at the tropical tropopause, Atmos. Chem. Phys., 9, 9647-9660, doi:10.5194/acp-9-9647-2009, 2009.

Selkirk, H. B., Vömel, H., Canossa, J. M. V., Pfister, L., Diaz, J. A., Fernández, W., Amador, J., Stolz, W., and Peng, G. S.: Detailed structure of the tropical upper troposphere and lower stratosphere as revealed by balloon sonde observations of water vapor, ozone, temperature, and winds during the NASA TCSP and TC4 campaigns, J. Gephys. Res., 115, D00J19, doi:10.1029/2009JD013209, 2010.
Stewart, D. J., Taylor, C. M., Reeves, C. E., and McQuaid, J. B.: Biogenic nitrogen oxide emissions from soils: impact on $\mathrm{NO}_{\mathrm{x}}$ and ozone over west Africa during AMMA (African Monsoon Multidisciplinary Analysis): observational study, Atmos. Chem. Phys., 8, 2285-2297, doi:10.5194/acp-8-2285-2008, 2008.

Thompson, A. M., Witte, J. C., Smit, H. G. J., Oltmans, S. J., Johnson, B. J., Kirchhoff, V. W. J. H., and Schmidlin, F. J.: Southern Hemisphere Additional Ozonesondes (SHADOZ) 1998-2004 tropical ozone climatology: 3. Instrumentation, station-to-station variability, and evaluation with simulated flight profiles, J. Geophys. Res., 112, D03304, doi:10.1029/2005JD007042, 2007.

Toon, O. B., Starr, D. O., Jensen, E. J., Newman, P. A., Platnick, S., Schoeberl, M. R., Wennberg, P. O., Wofsy, S. C., Kurylo, M. J., Maring, H., Jucks, K. W., Craig, M. S., Vasques, M. F., Pfister, L., Rosenlof, K. H., Selkirk, H. B., Colarco, P. R., Kawa, S. R., Mace, G. G., Minnis, P., and Pickering, K. E.: Planning, implementation, and first results of the Tropical Composition, Cloud and Climate Coupling Experiment (TC4), J. Geophys. Res., 115, D00J04, doi:10.1029/2009JD013073, 2010.

Viciani, S., D’Amato, F., Mazzinghi, P., Castagnoli, F., Toci, G., and Werle, P.: A cryogenically operated laser diode spectrometer for airborne measurement of stratospheric trace gases, Appl. Phys. B 90, 581-592, 2008.

Voigt, C., Schlager, H., Roiger, A., Stenke, A., de Reus, M., Borrmann, S., Jensen, E., Schiller, C., Konopka, P., and Sitnikov, N.: Detection of reactive nitrogen containing particles in the tropopause region - evidence for a tropical nitric acid trihydrate (NAT) belt, Atmos. Chem. Phys., 8, 7421-7430, doi:10.5194/acp-8-7421-2008, 2008

Volk, C. M., Riediger, O., Strunk, M., Schmidt, U., Ravegnani, F., Ulanovsky, A., and Rudakov, V.: In situ Tracer Measurements in the Tropical Tropopause Region During APE-THESEO, Eur. Comm. Air Pollut. Res. Report 73, 661-664, 2000.

Williams, J., Fischer, H., Hoor, P., Poeschl, U., Crutzen, P. J., Andreae, M. O., and Lelieveld, J.: The influence of the tropical rain forest on atmospheric $\mathrm{CO}$ and $\mathrm{CO}_{2}$ as measured by aircraft over Surinam, South America, Chemosphere - Global Change Sci., 3, 157-170, 2001.

Wu, S., Mickley, L. J., Jacob, D. J., Logan, J. A., Yantosca, R. M., and Rind, D.: Why are there large differences between models in global budgets of tropospheric ozone?, J. Geophys. Res., 112, D05302, doi:10.1029/2006JD007801, 2007.

Yushkov, V., Ouloanovsky, A., Lechenuk, N., Roudakov, I., Arshinov, K., Tikhonov, F., Stefnutti, L., Ravegnani, F., Bonafé, U., and Georgiadis, T.: A chemiluminescent analyzer for stratospheric measurements of ozone concentration (FOZAN), J. Atmos. Ocean. Tech., 16, 1345-1350, 1999.

Zöger, M., Afchine, A., Eicke, N., Gerhards, M.-T., Klein, E., McKenna, D. S., Mörschel, U., Schmidt, U., Tan, V., Tuitjer, F., Woyke, T., and Schiller, C.: Fast in situ stratospheric hygrometers: A new family of balloonborne and airborne Lyman-a photofragment fluorescence hygrometers, J. Geophys. Res., 104, 1807-1816, 1999. 